\title{
Contributions
}

\section{Anthony Edo* \\ The Impact of Immigration on Native Wages and Employment}

\begin{abstract}
This paper investigates the immigration impact on native outcomes using microlevel data for France. I find that immigration does not affect the wages of competing natives, but induces adverse employment effects. This finding is consistent with a wage structure that is rigid in France. The quality of the data allows to dig more deeply into the interpretation of the immigration impact. First, I show that immigrants displace native workers because they are more willing to work at lower wages due to lower outside options. Second, I find that natives on short-term contracts, who are less subject to wage rigidities, do experience wage losses due to immigration.
\end{abstract}

Keywords: immigration, wage rigidities, employment, naturalization JEL Classification: F22, J31, J61

\section{Introduction}

The literature in economics has stressed two important considerations when estimating the effects of immigration on the wages of natives. First, a particular immigration-induced supply shift does not only affect the wages of directly competing native workers. Immigration also induces complementarity effects on the wages of natives with different skills. In order to estimate the overall wage effect of immigration, economic studies thus have to capture both direct and complementarity effects induced by immigration (Ottaviano and Peri 2012).

Second, immigrant-induced supply shocks lead to economic adjustments in the medium and long run. In this regard, the literature points out the important

*Corresponding author: Anthony Edo, Paris School of Economics, 48 Boulevard Jourdan, 75014 Paris, France; Centre d'économie de la Sorbonne, University of Paris I Panthéon-Sorbonne, 106-112 Boulevard de l'Hôpital, 75647 Paris, France, E-mail: anthony.edo@univ-paris1.fr 
role played by capital accumulation (in response to immigration) in shaping the wage effects of immigration (Ortega and Peri 2009; Ottaviano and Peri 2012; Borjas 2013). Accounting for capital accumulation, Aydemir and Borjas (2007) and Borjas and Katz (2007) found no detrimental wage impact of immigration, while other studies found positive wage effects (Manacorda, Manning, and Wadsworth 2012; Ottaviano and Peri 2012; Brücker and Jahn 2011; Dustmann, Frattini, and Preston 2013). ${ }^{1}$

These findings naturally contrast with the negative wage effect documented in studies estimating partial and short-run effects of immigration on competing natives (see, e.g. the studies by Borjas (2003) and Orrenius and Zavodny (2007) for the United States; Borjas (2008) for Puerto Rico; Aydemir and Borjas (2007) for Canada; Bratsberg and Raaum (2012); Bratsberg et al. (2014) for Norway). In the short run, some empirical works also found depressive employment effects due to immigration (Angrist and Kugler 2003; Glitz 2012). This set of studies is consistent with the general sentiment that the native population suffers from the competition with equally skilled immigrants (Bauer, Lofstrom, and Zimmermann 2001; Mayda 2006). These beliefs are particularly stringent in Europe where one in two EU citizens is afraid of job losses due to immigrants (Thalhammer et al. 2001).

The sentiment that immigrants take jobs away from natives is partly based on the idea that immigrants and natives with similar skills differ considerably in their propensity to bargain over wages and working conditions. In particular, immigrants are generally viewed as more willing to accept lower wages and to exert more effort in production than competing natives. This dissimilarity may therefore lead firms to substitute immigrants for equally skilled native workers.

In the present paper, I examine this new issue by focusing on the direct effects of immigration on the wages and employment of competing native workers in the short run., ${ }^{2,3}$ The study focuses on the French labor market for two main reasons. First, France provides an excellent framework to also examine the role played by wage rigidities in shaping the labor market effects of immigration, a dimension that has been mostly overlooked in the existing literature. The French labor market is characterized by a wide set of institutional features which should affect the responsiveness of wages to immigrant-induced supply shocks (Card, Kramarz, and

1 Manacorda, Manning, and Wadsworth (2012) and Ottaviano and Peri (2012) rather show that immigration decreases the wages of previous immigrants.

2 I use the terms immigrant and foreign-born interchangeably here to refer to all individuals born outside France to parents who are not French citizens.

3 The present research aims at focusing exclusively on the partial elasticity of native outcomes to immigration in the short run. See Edo and Toubal (2015) for a long-run analysis on the overall impact of immigration on wages in France. 
Lemieux 1999; Saint-Paul and Cahuc 2009), such as minimum wage laws, generous unemployment benefits, collective bargaining coverage and strict employment protection. Second, a rich dataset is available for France. It provides a wide set of demographic, social and employment characteristics at the individual level. These microlevel data are provided from 1990 to 2002, a period over which the share of migrants in the labor force increased from $6.5 \%$ to $8.5 \%{ }^{4}$

The richness of the French data allows to show a strong dissimilarity between immigrants and natives in terms of employment conditions. Controlling for a wide range of observables (such as education, experience, job tenure, region of residence and occupation), I find that foreign-born workers exhibit a $2-3 \%$ lower wage and they are more likely to do late hours, work at night or on the weekends than similar natives. A reason behind this gap in employment conditions is that immigrants are more willing to accept lower wages and harder working conditions than equally productive natives.

This interpretation is supported by the fact that immigrants have lower outside options (Malchow-Møller, Munch, and Skaksen 2012; Battisti et al. 2014), such as lower job market opportunities. ${ }^{5}$ Immigrants also have different cultural norms than natives, so their expectations about their wages and working conditions are lower than similarly skilled natives (Constant et al. 2010) - e.g. immigrants may be more willing to work at lower wages because their reference is the prevailing wage in their country of origin (Wilson and Jaynes 2000). The discrepancy between natives and immigrants in terms of outside options and cultural norms is consistent with Constant et al. (2010) who find (for Germany) that immigrants have lower reservation wages (i.e. the crucial wage above which an individual is willing to work) than equally skilled natives.

As a result, immigrants may be relatively more attractive/profitable for firms than equally productive natives. ${ }^{6}$ In fact, the employment of immigrants may

4 Over this period, the average number of new entrants by year is around 145,000 (Thierry 2004). 5 For instance, immigrants (especially non-citizens) have a limited access to public sector jobs. These employment restrictions apply in many countries, such as Canada (DeVoretz and Pivnenko 2005) and the United States (Yang 1994; Bratsberg, Ragan, and Nasir 2002).

6 Here, I assume that immigrant and native workers belonging to a particular skill group (i.e. immigrants and natives who are equally educated and have the same age) are interchangeable in production or, more precisely, "perfect substitutes.” In Supplementary Material, I show that this assumption is verified in my data. Similar results are also found by Edo and Toubal (2015) for France over the period 1990-2010. Perfect substitutability implies that immigrants and natives of similar education and experience are equally productive - i.e. one unit of immigrant labor produces the same amount of output as one unit of native labor. While immigrants and natives are equally productive (or perfect substitutes), immigrants are, however, more willing to accept lower wages and harder working conditions. 
help firms to reduce their production costs, as well as to provide them with additional flexibility firms might need to adjust their production level. In addition, immigrant workers are less unionized, less informed about the employment protection legislation and less likely to claim their rights (Sa 2011). Thus, immigrant workers should be less likely to disrupt the production process than comparable native workers.

While immigrants and natives of similar education and experience are equally productive, they are not equally profitable for firms. According to Friedberg (2001, 1379), if "immigrants are prepared to work for less" (while they are similar to natives in all other respects), an immigration-induced increase in the number of workers should have a strong depressive impact on the wages of competing natives. However, in France, immigration should have a negligible impact on wages due to rigid institutions. Then, the question is how the employment of natives will be affected by immigration, especially when immigrants are relatively more attractive for firms. ${ }^{7}$

I use the "national skill-cell approach" by Borjas (2003) to investigate the labor market effects of immigration in France. This econometric strategy allows me to capture the own effect of immigrants on the wages and employment of competing natives in the short run. In the empirical analysis, I find that immigration does not affect the wages of competing native workers. This result is consistent with a wage structure that is rigid in France. However, since immigrants are relatively more attractive for firms, immigration decreases the employment of competing native workers - i.e. immigrants replace native workers in production. The baseline estimate implies that a 10\% increase in the share of immigrants relative to the native workforce in an education-experience cell decreases the employment rate of male natives by about $3 \% .^{8}$

The findings regarding the wage and employment responses to immigration support and generalize those of Glitz (2012) for Germany. Within the same regional residence and skill groups, he also finds no detrimental effects of immigration on native wages but adverse employment effect of immigration. The present study also echoes the results by Angrist and Kugler (2003), which

7 In the short run, the text book model of a competitive labor market suggests that higher levels of immigration should increase the level of unemployment in the economy (Saint-Paul and Cahuc 2009). In this model, the effects of immigration on the employment of competing natives are unpredictable. In fact, it may be that the newcomers do not find jobs (increasing the level of unemployment) and thus do not depress the employment of competing native workers. Also, it could be that negative employment effects due to immigration fall on immigrants only, and none on natives.

8 Interestingly, the estimated effect is of similar magnitude to that reported in Borjas (2003) who finds a wage adjustment to immigration by $3-4 \%$. 
show evidence of a negative effect of immigration on native employment for a panel of European countries, where labor market rigidities are prevalent. The present paper goes beyond these studies and contributes to the literature by extending the analysis to the underlying mechanisms behind the outcome reactions of natives - i.e. the insensitivity of wages and the negative employment effects induced by immigration.

On the one hand, I exploit an important source of (downward) wage rigidities in France, and I shed light on the crucial role played by the type of employment contract (short term/permanent) in shaping the wage effects of immigration. The decomposition by job contract is related to Babeckỳ et al. (2010) who show for European countries that permanent contracts - which are characterized by high firing costs, strict employment protection legislation and indefinite term - have a strong effect on downward wage rigidity. For France, I find that the population of natives under short-term contracts (i.e. a population who is less subject to downward wage rigidities) experiences huge wage losses due to immigration. This pattern is consistent with factor demand theory: when wages are not downwardly rigid, immigration lowers the wage of competing workers (at least in the short run). By contrast, the insensitivity of wages to immigration is even more striking for the population of native workers under permanent contracts. New to the literature, this asymmetric result supports the idea that immigration has (on average) no detrimental impact on the French wage structure because of downward wage rigidities.

On the other hand, I use the heterogeneity of migrants with respect to their citizenship status and show that the migrants who obtain French citizenship no longer depress native employment. ${ }^{9}$ Instead, the previous negative effects on native employment are completely attributable to the presence of non-naturalized immigrants. This second set of results supports the idea that the replacement mechanism operating between immigrants and natives lies in important differences between these two groups in terms of outside options and cultural norms. Indeed, the migrants who became French citizens tend to have similar behaviors to natives, since the naturalization leads to higher outside options, such as superior employment opportunities (Bratsberg, Ragan, and Nasir 2002; Fougere and Safi 2009) or equal access to social benefits with natives (Math 2011). Moreover, since the French citizenship acquisition depends on the integration level of migrants, it is very likely that the naturalized immigrants adopt the norms of natives because of higher levels of integration (compared to the non-naturalized migrants). Thus, naturalization should improve the position of

9 Notice that immigrants can become naturalized (through citizenship acquisition) or stay nonnaturalized. 
immigrants in the bargaining process with respect to firms, ${ }^{10}$ leading the naturalized immigrants to become as profitable as comparably skilled natives. As a result, firms no longer have incentives to replace native workers by the naturalized immigrants.

Finally, I divide the non-naturalized immigrants into EU citizens and nonEU citizens. The reason for this disaggregation is that European immigrants enjoy more privileges due to the single market and they are coming from countries that are geographically, economically and culturally close to France. I find that the negative employment effects are mainly driven by the nonEuropean immigrants - those immigrants with the poorest outside options. This finding is consistent with the former results.

The remainder of this paper proceeds as follows. Section 2 presents information on the French institutions that might affect the adjustment of wages and discusses the expected effects of an immigration shock on the French labor market. Section 3 describes the data and methodologies used in the paper. Section 4 investigates immigrant-native dissimilarities in wages and working conditions. This section also reports the estimated impact of immigration on native outcomes. Section 5 and 6 go beyond the average impact of immigration and underline the importance of job contracts and migrants' nationality in shaping the immigration impact. The last section concludes.

\section{Theoretical Effects of Immigration and Wage Rigidities}

\subsection{The French Institutional Setting}

This section discusses the French institutional features that may affect downward wage rigidities, and in fine the responsiveness of wages to labor supply shocks.

\subsubsection{Minimum Wage, Unemployment Benefits and Bargaining Institutions}

In comparison to the United States, Card, Kramarz, and Lemieux (1999) show that France has three main institutional features that should prevent wage

10 This may also explain why naturalization leads to higher earnings (Bratsberg, Ragan, and Nasir 2002; Steinhardt 2012). 
adjustment: minimum wage laws, generous unemployment benefits and high collective bargaining coverage.

First, France is characterized by the prevalence of a high minimum wage at the national level which applies to all workers. In France, the minimum wage relative to average wages of workers represents 50\% over the 1990 s, whereas it is equal to 35\% in the United States (Card, Kramarz, and Lemieux 1999). The proportion of French employees paid at the minimum wage was around 10\% between 1990 and 2002 (DARES 2013).

An alternative set of institutions that may reinforce downward wage rigidities in France is the high levels of unemployment benefits and income support programs for non-workers (Nickell 1997). As indicated in Cohen, Lefranc, and Saint-Paul (1997), generous welfare state benefits should increase the reservation wage of French workers. Thus, some workers may not accept pay cuts or to be paid less than what they could receive from unemployment insurance or welfare payments (Saint-Paul and Cahuc 2009).

Third, collective bargaining institutions and the wage-setting structure are important factors in the determination of downward wage rigidity (see, e.g. Dickens et al. 2007; Babeckỳ et al. 2010). In European countries where the dominant level of wage bargaining takes place outside the firm (at the sector, province or national level), ${ }^{11}$ wages tend to be downwardly rigid and they do not respond to economic shocks (Babeckỳ et al. 2010, 2012; Messina et al. 2010). By contrast, Babeckỳ et al. (2012) show that firm-level collective agreements tend to enhance downward wage flexibility (providing firms with additional flexibility). In fact, at the firm level, unions (and employees) are more willing to accept wage cuts because they better understand the negative effects of wage rigidity on firm-level profitability and future employment (Du Caju, Fuss, and Wintr 2009; Babeckỳ et al. 2012).

In France, wage bargaining takes place primarily at the industry level. Industry-level bargaining sets minimum pay scales for more than two-thirds of the labor force, while firm-level agreements cover about one-fifth of workers (Avouyi-Dovi, Fougère, and Gautier 2009). ${ }^{12}$ Given the predominant role of sector-level collective wage bargaining in wage-setting practices in France, wages are likely to be downwardly rigid. Moreover, France is characterized by the existence of extension procedures and a high level of collective bargaining

11 The United Kingdom and the United States are characterized by highly decentralized wage bargaining systems, where negotiations are made at the firm-level (Cahuc and Zylberberg 2004). 12 Notice that the "effective" wage received by employees is generally higher than the minimum wage which is negotiated at the industry level. If the negotiated minimum wage is lower than the national minimum wage, then the latter applies. 
coverage - i.e. agreements negotiated by unions and employer associations cover most the workforce. ${ }^{13}$ As shown by Babeckỳ et al. $(2010,2012)$ and Messina et al. (2010) for a large panel of European countries, the wage bargaining coverage is positively associated with downward wage rigidity. The wide coverage of collective agreements in France should therefore reinforce wage rigidity.

\subsubsection{Job Contracts}

Another institutional aspect that influences wage rigidity is related to how difficult it is for firms to terminate a match with an employee (Nickell 1997). In fact, when it is very costly to terminate a match, workers have more leeway in wage negotiations, which in turn lead to greater wage rigidity. In this regard, Babeckỳ et al. (2010) show for European countries that permanent contracts - which are characterized by high firing costs, strict employment protection legislation and indefinite term - have a strong effect on downward wage rigidity. Given that $90 \%$ of the stock of French employees has permanent contracts, the rigidity of the French wage structure should be therefore strengthened.

As in other European countries, French firms are allowed to hire workers on two types of employment contracts (Cahuc and Postel-Vinay 2002): the CDI, Contrat à Durée Indéterminée (permanent contract) and the CDD, Contrat à Durée Déterminée (short-term contract). The CDI is an indefinite-term contract with no end date, representing the normal form of contract in France. The CDD is a fixedterm contract for a specific duration of employment.

In principle, a CDD can be signed for a temporary and precise task (replacement in case of absence, temporary or seasonal demand shock). ${ }^{14}$ Short-term contracts are characterized by limited duration as well as limited renewal possibilities. They can only be renewed once and its length, including renewal, cannot exceed 18 months (24 months for youth employment programs). Employers can transform short-term contracts into a permanent contract - the rest of short-term contracts being terminated at no cost. ${ }^{15}$

13 The fact that workers are covered by wage agreements without being members of trade unions may explain why France has a proportion of unionized workers lower than $10 \%$.

14 Moreover, selection and testing of future permanent employees is allowed under such contracts.

15 At the beginning of the 1990s, one-third of all short-term employment contracts were converted to permanent contracts at their termination (Abowd, Corbel, and Kramarz 1999). 
Inasmuch short-term contracts have a fixed duration (with a mean duration of 1 year and a median duration of 7 months), ${ }^{16}$ termination of a CDD is not an issue. By contrast, permanent contracts have an indefinite term and the termination of a CDI is a complex process inducing high bureaucratic and financial costs (Gash and McGinnity 2007; Kramarz and Michaud 2010). Permanent contracts are thus subject to strict employment protection (Blanchard and Landier 2002). Employer-initiated termination of a permanent employee can take several forms. ${ }^{17}$ Firing for "serious misconduct" and voluntary quits exempt the employer from making a severance payment. For all other types of terminations (layoff, retirement), the employer has to make a severance payment (see Goux, Maurin, and Pauchet 2001; Abowd and Kramarz 2003 for details). ${ }^{18}$

While it is difficult and costly to terminate a CDI, the termination of a CDD is not an issue. This explains why firms mainly use short-term contracts to adjust their production level (Goux, Maurin, and Pauchet 2001). The asymmetry between job contracts in termination cost also explains why the entry and exit of workers on short-term contracts is a main driver of job turnover in France (Abowd, Corbel, and Kramarz 1999). ${ }^{19}$

Moreover, thanks to the limited length of short-term contracts, firms are able to constantly adjust their wage bills through job turnover when hiring new employees (i.e. when a new CDD starts) or after one renewal. In particular, a negative economic shock may lead firms to hire new employees at lower wages than those who terminated their job contract. ${ }^{20}$ Therefore, the population of workers under short-term contracts (high turnover) should be less subject to downward wage rigidities than the population of workers under permanent contracts (low turnover). The lower degree of (downward) wage rigidities for temporary employees is supported by the fact that they have more power in the wage-setting process than permanent workers. First, workers under permanent contracts are more protected by labor unions (Amossé and Pignoni 2006).

16 In the French LFS (1990-2002), 10.3\% of (full-time male) native workers had a CDD and out of these $10.3 \%, 75 \%$ had a contract duration of less than 1 year. Over the same period, the data indicate that $12.6 \%$ of the stock of male immigrants is on CDD.

17 The termination of a CDI can be also initiated by employees.

18 In the case of a lay-off, firms must prove the needs to reduce their employment. In France, employees can challenge the legality of their dismissal bringing their cases to court (Gash and McGinnity 2007).

19 Each year, two-thirds of all hiring is on short-term contracts.

20 In other words, firms should use the turnover of workers under short-term contracts as a tool to achieve labor cost flexibility. This is supported by Babecky et al. (2012) who show that the main strategy used by French firms to adjust their labor costs is through labor turnover. 
Second, these workers tend to have higher reservation wages because they are eligible to higher amounts of unemployment benefits (Ortega and Rioux 2002).

Finally, I use my data to examine the degree of wage rigidity for the population of native workers under permanent and short-term contracts. ${ }^{21}$ Figure 2 of Supplementary Material shows that the wage variations experienced by the subsample of native workers under short-term contracts are much more (i) pronounced and (ii) negative than the subsample of native workers under permanent contracts. This result is perfectly consistent with the fact that workers under short-term contracts are less subject to downward wage rigidities than those under permanent contracts.

By affecting the degree of wage rigidity, the type of job contracts (short run/ permanent) should therefore affect the responsiveness of wages to immigrationinduced labor supply shocks. Thus, immigration should affect differently the wages of competing natives according to whether they have permanent or shortterm contracts. This is tested in Section 5.

\subsection{The Theoretical Effects of Immigration}

The impact of migrations on the labor market is usually studied within the framework of a competitive model of labor demand where wages are perfectly flexible. In the short run, a competitive model suggests that higher levels of immigration should lower the outcomes of competing workers and increase those of complementary workers. In the long run, these models predict that the host country's wage is independent of migration. The physical capital response to immigration offsets the fall of the capital-labor ratio. The economy therefore returns to its pre-immigration equilibrium, where wage and employment levels are exactly the same as they were prior to the immigrant influx.

These theoretical results are unlikely to apply to France due to labor market frictions. In fact, French firms may be unable to lower wages after an immigration shock. Within the framework of downward inflexible wages, if natives and immigrants are complements, an immigration shock should increase native wages and employment (as predicted by the standard competitive model). In fact, if institutional factors resist the downward wage pressure, it is very likely

21 Another type of contracts is governed by the same rules as the CDD: the temporary work contract. The main difference is that in the case of a temporary work contract, there are three parties involved: the employee, the employment agency and the employing company. Companies can only use a temporary employee to perform short-term activities. In the empirical analysis, I thus define a short-term contract as a traditional CDD or a temporary job contract. 
that they allow for upward adjustments. However, if natives and immigrants are substitutes, immigration should not affect wages, but increase the level of unemployment in the economy (Saint-Paul and Cahuc 2009).

For France, Edo and Toubal (2015) show that immigrants and natives with similar education-experience profiles are perfect substitutes in the production process. $^{22,23}$ Therefore, an immigration supply shock is expected to have a very limited impact on the French wage structure. An inflow of migrants should thus be translated into an equal rise in the number of unemployed people. Yet, if immigration increases the level of unemployment, the short-term impact of migrants on native employment is unpredictable here. Two scenarios are possible. New migrants could (i) directly become unemployed or (ii) hurt native employment. ${ }^{24}$

As suggested by scenario (i), the non-adjustment of wages might prevent the newcomers from finding a job. Immigrants would thus become mechanically unemployed and would not affect native employment. As suggested by scenario (ii), immigration could also induce short-run depressive impacts on native employment through displacement effects. Especially, this possibility may arise if immigrants exhibit some attractive characteristics for firms (while they are identical to natives in all other respects), so immigrants are substituted for natives in the production process. In this regard, Section 4.1 is devoted to show that the immigrant population differs from the native population in important ways. In particular, natives and immigrants tend to have different outside options, cultural norms and therefore different labor market behaviors: immigrants are more inclined to accept lower wages and harder work conditions than equally productive natives. ${ }^{25}$ This dissimilarity between natives and immigrants leads immigration to depress the employment of equally skilled natives through a displacement mechanism. ${ }^{26}$

22 In Section A of Supplementary Material, I use the same estimation strategy as in Ottaviano and Peri (2012); Edo and Toubal (2015) to estimate the substitution elasticity between natives and immigrants for my period of interest (1990-2002). I find that similarly skilled immigrants and natives are perfect substitutes.

23 Prior empirical studies have reached mixed conclusions about the degree of substitutability between natives and immigrants (Aydemir and Borjas 2007; Borjas, Grogger, and Hanson 2012; Ottaviano and Peri 2012; Manacorda, Manning, and Wadsworth 2012).

24 First, notice that these scenarios are not exclusive to each other. Second, in both cases, newcomers impose a cost on society in terms of foregone output. But in scenario (ii), immigration leads to an additional cost in terms of unemployment benefits (D'Amuri et al. 2010).

25 Immigrants and natives of similar skills are equally productive (or perfect substitutes), but immigrants are more profitable for firms than similar natives.

26 The negative effect of immigration on native employment may be mitigated by incentives among firms to create jobs in order to increase their probability by hiring immigrants (who work at lower wages) - as predicted by search and matching models (Battisti et al. 2014; 


\section{Data and Methodologies}

\subsection{Data, Variables and Sample Description}

The empirical study is based on the French annual labor force survey (LFS) covering the period 1990 through 2002. This survey is carried out by the French National Institute for Statistics and Economic Studies (INSEE). ${ }^{27}$ This section describes the data and sample used to perform the study. Then, it presents the two sets of variables used to investigate (i) immigrant-native dissimilarities in employment conditions and (ii) the labor market effects of immigration.

\subsubsection{Data and Sample Selection}

The French LFS records much information about a random sample of around 150,000 individuals per year. ${ }^{28}$ Constructed from repeated cross sections carried out in the same way over 13 years, this pseudo-panel includes demographic characteristics (nationality, age, gender and marital status), social characteristics (educational attainment, age of completion of schooling and family background) as well as employment status, occupation, earnings, number of hours worked a week, etc.

In accordance with the literature on migration, I define an immigrant as a person who is foreign-born outside France to parents who are not French citizens. Some foreign-born individuals may thus have become French through citizenship acquisition while others have remained non-French (or non-naturalized). ${ }^{29}$ The data provide detailed information on individual nationality (more than 80 countries) and distinguish naturalized immigrants from others.

Chassamboulli and Palivos 2014). In fact, firms may be encouraged to open vacancies because they anticipate more profit as they will be able to pay lower wages to immigrants. Thus, immigration should lead firms to create jobs which, in turn, may increase native employment (especially when firms cannot discriminate between immigrants and natives before the match). 27 Institut National de la Statistique et des Etudes Economiques.

28 I use an individual weight (computed by the INSEE) to make the sample representative of the French population. For each observation the weight indicates the number of individuals each observation represents in the total population.

29 French nationality law is historically based on the principles of jus soli - i.e. transmission of citizenship on the basis of birth in the country - for children born to parents who are permanent residents. 
The employment survey gives human capital characteristics for each respondent, such as their education level, their age and the age when they completed their studies. The education level is divided into six categories: college graduate, some college, high school graduate, some high school, just before high school, no education. According to the International Standard Classification of Education (ISCED), those levels of education, respectively, correspond to (1) a second stage of tertiary education, (2) first stage of tertiary education, (3) postsecondary non-tertiary education, (4) (upper) secondary education, (5) lower secondary education and (6) a primary or pre-primary education.

Individuals with the same education, but with a different age or experience are unlikely to be perfect substitutes (Card and Lemieux 2001). Hence, I distinguish individuals in terms of their labor market experience. Following Mincer (1974), work experience is computed by subtracting for each individual the age of completion of schooling from reported age. ${ }^{30}$ This measure differs from the one used in the migration literature since the age of completion of schooling is usually unavailable. ${ }^{31}$

Finally, I follow most empirical studies and restrict my attention to men ${ }^{32}$ in the labor force (employed and unemployed individuals) aged from 16 to 64, who are neither enrolled at school nor self-employed (farmers and entrepreneurs), and who have between 1 and 40 years of labor market experience.

\subsubsection{First Set of Variables}

A first set of variables is used to investigate immigrant-native dissimilarities in employment conditions. For each worker, the survey reports the monthly wage

30 The age of completion of schooling is usually considered as a proxy for the entry age into the labor market - i.e. the starting point from which an individual begins to accumulate work experience. For a few surveyed individuals, the age of completion of schooling is very low, between 0 and 11 inclusive. Since individuals cannot start accumulating experience when they are too young, I have raised the age of completion of schooling for each surveyed individual to 12 if it is lower.

31 Empirical works rather assign a particular entry age into the labor market to the corresponding educational category.

32 Women are generally excluded from samples for two reasons. First, they have to face more frequent periods of inactivity or unemployment, so that the correspondence between their potential and effective experience tends to collapse. It is therefore difficult to make any sensible inference based on these grouped data. Second, "the inclusion of working women in the analysis introduces selection issues that are difficult to address and resolve" (Borjas 2014, 82). These issues have been widely emphasized and studied by the literature on labor supply (see, e.g. Heckman 1993). 
net of employee payroll tax contributions adjusted for non-response, as well as the number of hours worked per week. I use this information and compute the hourly wage for each worker to investigate wage inequalities. ${ }^{33}$ Wages are adjusted for inflation, by using the French Consumer Price Index computed by the INSEE, with 2000 as the reference base period.

The French LFS also provides original information on the working conditions experienced by workers in their current job. It records whether employed individuals work at night (from midnight to $5 \mathrm{am}$ ), at late hours (from $8 \mathrm{pm}$ to midnight), on Saturdays and Sundays. More precisely, the survey provides the frequency of those specific working conditions whether they are usual, occasional or never realized. I use these variables to build three dummies indicating if an employee usually works at night, at late hours or on the weekend (Saturdays or Sundays).

The richness of the French microlevel data allows to control for many variables that should affect immigrant-native inequalities. In addition to human capital information, the survey contains job characteristics. For each worker, the type of employment (public/private), the working time structure (full-time/part time) and the type of contract (short-term/permanent) are given. The data also provide an original variable indicating the entry year into a firm for each worker. I use this variable to compute the job tenure of workers. Occupations and regions of residence are also provided for each individual. The French LFS has the advantage to record 360 occupations. Finally, the LFS also reports family and social characteristics related to the number of children in the household, the marital status (single/couple) and the occupational category (over 29) of the respondent's father.

\subsubsection{Second Set of Variables}

This paper uses the skill-cell methodology from Borjas (2003) to investigate the labor market impact of immigration. This methodology aims at dividing out the national labor market into skill cells. The cells are built in terms of educational attainment $j$, experience level $k$ and calendar year $t$, each of them defines a skill group at a point in time for a given labor market. Individuals are then clustered into these skill cells according to their education-experience profile.

33 For $11 \%$ of workers (for whom hours worked are not regular and constant from one week to another), I use the number of hours worked during the previous week to compute their hourly wage. 
This paper uses four different labor market outcomes: the average monthly and hourly wages, the employment rate to population and the employment rate to labor force. These variables are computed using the individual weight provided by the INSEE. In order to have a homogeneous population of workers, we compute these four dependent variables on the basis of full-time employment. ${ }^{34}$

Both monthly and hourly wages are adjusted for inflation. To compute the average hourly wage in the cell $(j, k, t)$, I independently calculate the average monthly wage and the total amount of hours worked in each skill group. ${ }^{35}$ The employment rates are, respectively, equal to the employment of full-time native workers as a percentage of the overall native population aged from 16 to 64 (employed, unemployed and inactive) and as a percentage of the native labor force (employed and unemployed). Even if the second ratio is a better proxy for labor market opportunities, the comparison of these ratios should inform us on how immigration affects the participation rate of natives (equals to the employment rate to population divided by the employment rate to labor force). ${ }^{36}$

Following Borjas (2003), the immigrant supply shock experienced in a particular skill cell with educational attainment $j$, experience level $k$ at year $t$ is measured by $p_{j k t}$, the percentage of total labor supply in a skill group coming from immigrant workers:

$$
p_{j k t}=M_{j k t} /\left(N_{j k t}+M_{j k t}\right),
$$

with $N_{j k t}$ and $M_{j k t}$, respectively, the number of male natives and immigrants in the labor force located in the education-experience-time cell $(j, k, t)$. As well as native outcomes, the immigrant share is computed using an individual weight. The immigrant supply shock for each skill cell is computed on the basis of 31,309 to 34,994 individual observations per year, of which between $8.0 \%$ and $8.8 \%$ represent immigrants.

The graphs in Figure 1 illustrate the share of foreign-born workers for three education levels (high, medium and low - these education levels, respectively,

34 Notice that the econometric results are totally robust to the inclusion of part-time workers in the sample used to compute the dependent variables.

35 This procedure reduces the loss of observations. Although some workers do not report their wage income, they always state their number of hours worked.

36 The content and trend of the four dependent variables are reported in the Supplementary Material (Section B, see Tables 7 and 8). For each year, I provide the number of observations which was used to compute the dependent variables. For Table 8, I give the number of full-time native workers which was used to compute the numerator of both employment ratios. Both Tables 7 and 8 show consistent numbers: the levels of wages and employment increase with education and experience, except for the oldest workers who are systematically disadvantaged on the French labor market (d'Autume et al. 2005). 
(a)

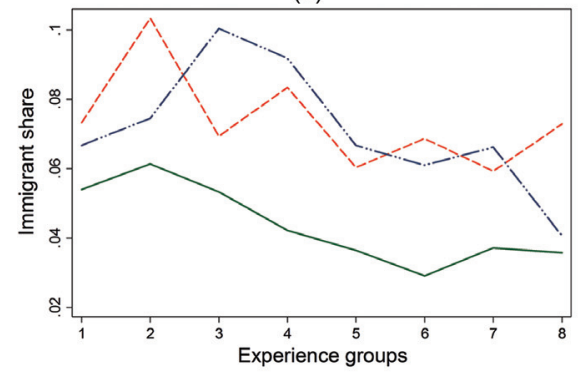

(c)

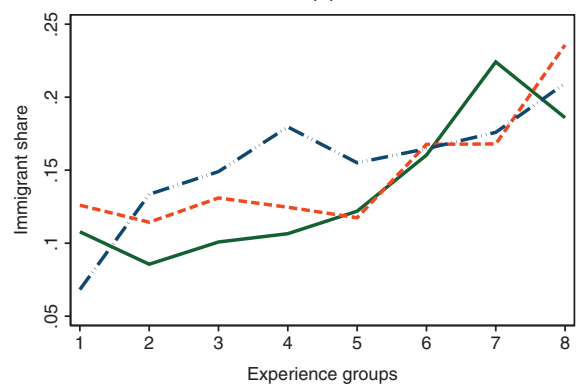

(b)

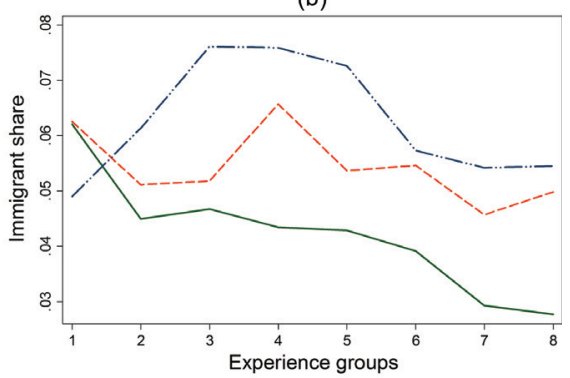

Figure 1: Immigrant share per cell in 1990, 1996 and 2002. (a) High level; (b) medium level and (c) low level.

Notes: The figure illustrates the supply shocks experienced by the different skill cells between 1990 and 2002. Experience groups denoted 1, 2, 3,.., 8 correspond, respectively, to an experience level equal to $1-5,6-10,11-15, \ldots, 36-40$ years. The population used to compute the immigrant share includes men participating in the labor force aged from 16 to 64 , not enrolled at school and having between 1 and 40 years of labor market experience. Selfemployed people are excluded from the sample.

correspond to college education, high school education and below than high school education) and 3 years (1990, 1996 and 2002). ${ }^{37}$ Eight experience groups are defined, each spanning an interval of 5 years. The figure shows that immigration increased the supply of the high- and medium-educated populations. These supply shifts did not affect all age groups within these populations equally. The immigrant supply shock experienced in the highly and medium-educated groups particularly increased in cells with more than 10 years of experience. The figure also indicates that immigrants are overrepresented in the low-educated segment of the labor market. However, this schooling group did not experience important supply shocks due to immigration between 1990 and 2002.

37 In the Supplementary Material, Table 9 supplements Figure 1 by providing the distribution of male natives and immigrants in the labor force per group of education over time. 


\subsection{Empirical Strategies}

This paper highlights a new source of heterogeneity between immigrants and natives to understand how immigration may depress the outcomes of equally skilled natives. I first exploit Mincer equations to examine the labor market dissimilarities in employment conditions between natives and immigrants. Second, I use the "national skill-cell approach," introduced by Borjas (2003), to measure the labor market impact of immigration.

\subsubsection{Extended Mincer Equations}

The study of labor market inequalities requires focusing on a non-randomly selected sample, that of workers. Yet, the productivity and behavior of workers may be different from individuals who are not included in this specific sample. Thus, the estimates of wage and work conditions inequalities may be biased due to a selectivity problem (Heckman, 1979; Blackaby et al. 2002). The Heckman two-stage estimation procedure is undertaken to address this potential issue. The vector of selection variables has to contain at least one element that is excluded from the second-stage regressions (Sartori 2003). Satisfactory identification requires data on factors that affect the labor market participation but do not directly wages. Following Glewwe (1996), I use marital status and family size as identifying instruments. In order to run the first-stage Heckman procedure, I thus use five covariates: the number of children under 18-year-olds in the household, a dummy variable indicating whether the individual is single or not, education, experience and its square. ${ }^{38}$

In order to capture the (unexplained) wage differential between natives and immigrants, I pool the cross-sectional observations over time and I estimate the following equation:

$$
\ln \left(w_{\text {iort }}\right)=\alpha_{0}+\alpha_{1} I_{i}+\alpha_{2} H_{i}+\alpha_{3} J_{i}+\zeta_{o}+\zeta_{r}+\zeta_{t}+\xi_{\text {iort }} .
$$

The dependent variable is the log hourly wage for each individual $i$, in occupation $o$ and region $r$ at time $t$. The immigrant status of an individual is captured by the term $I_{i}$ which is a dummy variable indicating if the employee is an

38 The first stage aims at estimating a selection equation by maximum likelihood as an independent probit model to determine the decision to enter the labor market, in order to generate a vector of inverse Mills ratios from the parameter estimates. The second step of the procedure then reruns the (benchmark) regression with the inverse Mills ratios included as an extra explanatory variable, removing the part of the error term correlated with the explanatory variable and avoiding the selection bias. 
immigrant. The term $H_{i}$ is a vector of control variables containing the human capital characteristics for individual $i$ such as the age of completion of schooling, the labor market experience and its square. Job characteristics $J_{i}$ control for job tenure and its square, part-time employment, the type of job contract, public sector jobs and types of work (nights and weekends). In order to control for occupationspecific factors, I also add a vector of occupational dummies $\zeta_{o}$. I also include region and time dummy variables, respectively, denoted as $\zeta_{r}$ and $\zeta_{t}$, as geography and cyclical effects might affect individual wages. $\xi_{\text {iort }}$ is the error term.

The prevalence of a high minimum wage in France should lead to a censoring problem and bias the estimates of $\alpha_{1}$. The discontinuity of the hourly wage distribution is addressed using Tobit estimation. For each year of the survey, different censoring values for the hourly minimum wage are thus used.

In order to investigate immigrant-native disparities in work conditions, three dummies indicating if an employee works (i) at night, (ii) at late hours or (iii) on the weekend are used as dependent variables. Then, I can estimate three probit equations to examine whether those specific working conditions are, ceteris paribus, more widespread among immigrant workers. I use the same set of regressors than in eq. [2].

\subsubsection{The Skill-Cell Methodology}

I use the skill-cell methodology to examine the immigration impact on native outcomes. This methodology is the most suitable to investigate how the outcomes of natives can react due to an increase in the number of comparably skilled immigrants.

The skill-cell methodology is based on the following equation:

$$
y_{j k t}=\alpha+\beta\left(p_{j k t}\right)+\delta_{j}+\delta_{k}+\delta_{t}+\delta_{j} \times \delta_{t}+\delta_{k} \times \delta_{t}+\delta_{j} \times \delta_{k}+\xi_{j k t},
$$

where $y_{j k t}$ is the labor market outcome at period $t$ for native men with education $j$ and experience $k$ and $p_{j k t}$ is the immigrant share. In addition to including the vectors of fixed effects for schooling $\delta_{j}$, experience $\delta_{k}$ and time $\delta_{t}$, this model also contains a full set of second-order interactions for schooling by time, experience by time and schooling by experience. The linear fixed effects in eq. [3] control for differences in labor market outcomes across schooling groups, experience groups and over time. Interactions $\delta_{j} \times \delta_{t}$ and $\delta_{k} \times \delta_{t}$ control for the possibility that the impact of education and experience on outcomes changed over time, whereas $\delta_{j} \times \delta_{k}$ control for differences in the experience profile by schooling group. The standard errors will be corrected for heteroskedasticity and clustered around education-experience groups to adjust for possible serial correlation. 
The skill-cell approach identifies the labor market impact of immigration by examining how the evolution of outcomes within skill cells has been affected by differences in the size of the supply shocks induced by immigration. The fact that migrants may not be randomly distributed across skill cells would lead to biased estimates of $\beta$. Suppose that the labor market may attract foreign-born workers mainly in those skill cells where wages and employment are relatively high. There would be a spurious positive correlation between $p_{j k t}$ and the labor market outcomes of natives (Borjas 2003). As a result, an instrumentation strategy would be necessary if the ordinary least squares (OLS) estimates from the skill-cell approach indicate that $\hat{\beta}>0$. If the estimates rather indicate that $\hat{\beta}<0$, the correction of the (upward) bias would induce the true immigration impact to be more negative. Within that case, the endogeneity of the immigrant share is therefore less problematic. In the remaining of this paper, I will use the fact that when the estimates of $\beta$ are negative, they have to be interpreted as lower bounds of the true impact of immigration to reinforce the empirical results.

On the other hand, the estimates from the skill-cell approach are very likely to be sensitive to how skill groups are defined. Especially, a small sample size per skill cell tends to attenuate the impact of immigration because of sampling error in the measure of the immigrant supply shift $p_{j k t}$ (Aydemir and Borjas 2011). In order to correct for this potential attenuation bias, the paper follows two strategies. First, I build alternative samples with different structures of education-experience cells, so that one sample only contains 12 skill cells per year. Second, in addition to using all years of the sample separately to compute our variables, I will also merge years by pair (i.e. I drop the year 1990 and merge 1991/1992, 1993/1994, 1995/1996, 1997/1998, 1999/2000 and 2001/2002) to substantially increase the sample size per cell.

Our baseline sample combines three categories of educational attainment $j=3$ and eight experience groups $k=8$, so that the labor market is divided into 24 segments. ${ }^{39}$ In order to build the three education groups, I merge the two highest levels of education [Second stage of tertiary education - First stage of tertiary education], the two medium ones [Post-secondary nontertiary education - (Upper) secondary education] and the two lowest ones [Lower secondary - Primary education and Pre-primary education]. ${ }^{40}$ I also use eight groups of experience (Borjas 2003; Aydemir and Borjas 2007;

39 In their empirical study, D’Amuri et al. (2010); Gerfin and Kaiser (2010); Elsner (2013a) also use three education groups.

40 While the high level of education regroups individuals with some college or more, both medium- and low-education levels, respectively, refer to individuals with high school education and less than a high school education. 
D'Amuri et al. 2010; Ottaviano and Peri 2012), each spanning an interval of 5 years of experience $[1-5 ; 6-10 ; 11-15 ; 16-20 ; 21-25 ; 26-30 ; 31-35 ; 36-40]$.

The two alternative samples make up four experience groups $k=4$ (as in Felbermayr, Geis, and Kohler 2010; Gerfin and Kaiser 2010; Elsner 2013b), each spanning an interval of 10 years of experience. The first alternative sample contains three education classes $j=3$ while the other contains six $j=6$. The sample with 12 skill cells (three education groups and four experience groups) should correct for the attenuation bias my estimates may suffer (Aydemir and Borjas 2011). Also, it allows to attenuate the impact of any potential bias regarding the experience measure, and in particular, the fact that employers may evaluate the experience of immigrants differently from that of natives.

The sample with six rather narrower education levels is built to test the possibility of an educational downgrading among immigrants. Indeed, immigrants could accept jobs requiring a lower level of education than they have (see, e.g. Dustmann, Frattini, and Preston (2013)) for the United Kingdom, Cohen-Goldner and Paserman (2011) for Israel as well as Mattoo, Neagu and Özden (2008) for the United States). Therefore, within a broad education group, immigrant workers could compete with the less educated natives of the cell. In this case, the labor market segmentation along three (broad) education levels could fail to appropriately identify groups of workers competing for the same jobs. Hence, a more detailed education partition with six education groups should allow to deal with the impact of immigrants on equally educated native workers. In particular, if immigrants downgrade upon arrival, the estimated effect on native outcomes should differ from a sample with six education groups to a sample with only three.

To sum up, the baseline sample divides the labor market into $24(j=3 \times$ $k=8)$ skill cells, while the two alternative samples divide it into $12(j=3 \times k=4)$ and $24(j=6 \times k=4)$ segments.

\section{The Econometric Analysis}

\subsection{Labor Market Conditions between Natives and Immigrants}

This section is devoted to shed light on a new type of heterogeneity between natives and immigrants: immigrants are more inclined to accept lower wages and harder working conditions than equally skilled natives. The main reason is that immigrants have lower outside options and different cultural norms. 


\subsubsection{Econometric Results}

Table 1 examines the level of inequalities in wages and work condition between natives and immigrants. The sample used is the pooled cross section from 1990 to 2002. The left-hand side (first two columns) of Table 1 reports the estimates of $\alpha_{1}$ from eq. [2] for two specifications: one correcting for selection and the other for censoring (around 15,000 observations are left censored). The estimates indicate a negative wage premium of $2-3 \%$ for immigrants, while controlling for a wide set of socioeconomic variables (i.e. education, experience, job tenure, region of residence, occupation, etc.). This is in accordance with other findings for France (Algan et al. 2010).

Table 1: Immigrant-native employment condition disparities (1990-2002).

\begin{tabular}{|c|c|c|c|c|c|}
\hline \multirow[b]{3}{*}{ Immigrants } & \multicolumn{5}{|c|}{ Dependent variable } \\
\hline & \multicolumn{2}{|c|}{ Log hourly wage } & \multirow{2}{*}{$\begin{array}{c}\text { Night work } \\
0.04^{\star \star} \\
(2.15)\end{array}$} & \multirow{2}{*}{$\begin{array}{c}\text { Late hours } \\
\begin{array}{c}0.08^{\star \star \star} \\
(5.34)\end{array}\end{array}$} & \multirow{2}{*}{$\begin{array}{c}\text { Weekend } \\
\begin{array}{c}0.07^{\star \star \star} \\
(6.09)\end{array}\end{array}$} \\
\hline & $\begin{array}{l}-0.02^{\star \star \star} \\
(-9.03)\end{array}$ & $\begin{array}{l}-0.03^{* * *} \\
(-11.92)\end{array}$ & & & \\
\hline Inverse mills ratio & $\begin{array}{l}-0.05^{\star \star \star} \\
(-5.88)\end{array}$ & - & $\begin{array}{l}0.16^{\star \star \star} \\
(3.51)\end{array}$ & $\begin{array}{l}0.29^{\star \star \star} \\
(6.49)\end{array}$ & $\begin{array}{r}0.05 \\
(1.51)\end{array}$ \\
\hline Adj. $R^{2}$ & 0.49 & 0.40 & 0.36 & 0.30 & 0.28 \\
\hline $\begin{array}{l}\text { Observations } \\
\text { Control variables }\end{array}$ & 349,313 & 349,462 & 386,676 & 292,928 & 394,287 \\
\hline Human capital & Yes & Yes & Yes & Yes & Yes \\
\hline Job characteristics & Yes & Yes & Yes & Yes & Yes \\
\hline Occupation dummies & Yes & Yes & Yes & Yes & Yes \\
\hline Region dummies & Yes & Yes & Yes & Yes & Yes \\
\hline $\begin{array}{l}\text { Time dummies } \\
\text { Estimation procedures }\end{array}$ & Yes & Yes & Yes & Yes & Yes \\
\hline Heckman & Yes & No & Yes & Yes & Yes \\
\hline Tobit estimation & No & Yes & - & - & - \\
\hline
\end{tabular}

***, **, *Statistical significance from zero at the $1 \%, 5 \%, 10 \%$ significance level. $t$-Statistics are indicated in parentheses below the point estimate.

Notes: Estimations are conducted on workers who have between 1 and 40 years of experience. On the right-hand side, the dependent variables are dummies equal to 1 when the employee works at night, at late hours or on the weekend and to 0 otherwise. Human capital control variables include schooling, experience and its square. Job characteristics contain the job tenure, part-time, permanent contract and public sector dummies, as well as two additional dummies indicating if an employee works at night and on the weekend. $t$-Statistics are derived from heteroskedastic-consistent estimates of the standard errors. Regressions are weighted using an individual weight computed by the INSEE. 
It is worth noting that the inverse Mills ratio is negative and statistically significant in column 1. Similar results are reported by Blackaby et al. (2002) who examine the wage differential between white and black for the United Kingdom. The significance of the inverse mills ratio highlights a selectivity into employment. Unobserved factors that affect the decision to work also affect wages. ${ }^{41}$ The negative selectivity term suggests that if unemployed people were to find a job, they would have higher earnings as compared to individuals with similar characteristics already in jobs. "This result is compatible with such individuals setting higher reservation wages and is consistent with their lower employment probability" (Blackaby et al. (2002, 285)).

Labor market disparities between natives and immigrants are also marked in terms of working conditions. The right-hand side of Table 1 reports the likelihood of working at night, at late hours and on the weekend for migrants. Each specification corrects for sample selection bias. The estimated coefficients are always significantly positive, implying that migrant workers are more likely to do late hours, work at night or on the weekends than comparable native workers. The significant and positive selectivity terms (except for the last column) implies that the unobserved factors which affect the decision to work also affect the probability of having difficult working conditions. Those who select into employment endure harder working conditions than a random drawing from the population of unemployed with a comparable set of characteristics would endure. This is consistent with the idea that unemployed individuals are less willing to have difficult work conditions.

Our finding of immigrant-native disparities in work conditions is consistent with Giuntella (2012) for Italy and Coutrot and Waltisperger (2009) for France. While the first study finds that immigrants are more likely to work at nonstandard hours (i.e. evenings, nights and Sundays), Coutrot and Waltisperger (2009) show with a subjective survey that, ceteris paribus, immigrants are more exposed to painful and tiring occupations than natives.

\subsubsection{Interpretations and Implications}

One important explanation behind the labor market disparities (in wages and work conditions) between natives and immigrants lies in a behavioral gap. ${ }^{42}$

41 This implies that the characteristics of the employed population in the labor force do not mirror the active population (employed and unemployed) - i.e. (male) workers are not representative of the (male) population.

42 The disparities in employment conditions between natives and immigrants are also very likely to be due to other factors. For instance, the component of the unexplained wage 
Ceteris paribus, immigrant workers are more willing to accept lower wages and harder working conditions than native workers with similar human capital and job characteristics. This is supported by the fact that immigrants tend to have lower outside options than equally skilled natives (Wilson and Jaynes 2000; Malchow-Møller, Munch, and Skaksen 2012; Battisti et al. 2014), as well as different cultural norms (Constant et al. 2010).

Two main reasons can explain why immigrants have lower outside options than natives (at least in the French context). On the one hand, the probability of finding a job is lower for migrants. First, immigrants have a limited access to the labor market: a wide number of jobs in the public sector requires the French citizenship in order to be filled. ${ }^{43}$ In this regard, Math and Spire (1999) have documented that immigrants have access to only $70 \%$ of all available jobs in France. Second, immigrants may have lower knowledge/information about the labor market due to cultural barriers and/or because they are newcomers (Erdmans 1995).

On the other hand, the cost of being unemployed is higher for immigrants. First, the eligibility to social welfare benefits that ensures a minimum income (or "social minima)" is limited for immigrants in France (Math 2011). Although 5 years of residence are required since 2003, the eligibility to "social minima" required 3 years over the period 1990-2002. Second, the conditions to renew work permits or obtain French citizenship strongly require a job (among immigrants) to attest to a high level of social and economic assimilation. ${ }^{44}$

Immigrants and natives also differ in terms of their cultural norms. In general, immigrants come from countries with inferior labor market outcomes (lower wages or higher unemployment). Hence, their expectations about their wages and working conditions are lower because their reference is the prevailing

differentials between workers could be also related to discrimination (Kee 1995; Blackaby et al. 2002; Weichselbaumer and Winter-Ebmer 2005), or skill transferability problems where education and experience obtained in foreign countries have much lower returns (Chiswick, Lee, and Miller 2005).

43 These types of employment restrictions are also prevalent in many countries, such as Austria (Kogan 2003), Belgium (Corluy, Marx, and Verbist 2011), Canada (DeVoretz and Pivnenko 2005), Germany (Euwals et al. 2010; Steinhardt 2012), Netherlands (Bevelander and Veenman 2006; Euwals et al. 2010), Norway (Hayfron 2008; Bratsberg and Raaum 2011), the United States (Yang 1994; Bratsberg, Ragan, and Nasir 2002) and Sweden (Scott 2008).

44 The French Code Civil of 1993 (formerly the Code de la nationalité) does not provide a legal claim for naturalization. Even if the applicant fulfills all requirements, $s /$ he can be refused by means of a discretionary decision. According to Art. 21 of the Code Civil of 1993, the actual requirements are a minimum residence time of 5 years, no criminal record, secured income, as well as societal and cultural integration. For complementary information on naturalization in France, see Hagedorn (2001); Rallu (2011). 
employment conditions in their country of origin (Wilson and Jaynes 2000). In addition, a sociological work by Sayad (1999) underlines the fact that immigrants are forced into a sort of "social hyper-correctness" which makes them less inclined to complain about their condition.

As a result, the immigrant population differs from the native population because the former has lower outside options and different cultural norms. This gap between immigrants and natives is consistent with Constant et al. (2010), who show for Germany that immigrants tend to have lower reservation wages (i.e. the crucial wage above which an individual is willing to work) than equally skilled natives. Thus, immigrants should be more willing to accept lower wages, as well as to exert more effort in the production process than equally productive natives. ${ }^{45}$

The differences between immigrants and natives in terms of outside options and cultural norms should therefore create a gap between the costs for firms of employing immigrants relative to employing natives. First, immigrants may allow firms to produce at lower labor costs. Second, immigrants may provide firms with additional flexibility they may need to adjust their production level. For instance, immigrants may be willing to accept last-minute changes. Third, immigrant workers may be relatively more attractive for employers because immigrants are less likely to be unionized, informed about the employment protection legislation and they are less likely to claim their rights compared to natives (Sá 2011). Thus, immigrants should be less likely to disrupt the production process compared to natives with similar education.

Immigrants, being more profitable for firms than equally productive natives, should increase (or perhaps exacerbate) the labor market competition. Thus, immigration should (strongly) depress the outcomes of competing native workers (Friedberg 2001). However, within a framework of downward wage rigidities, a displacement effect may arise after an influx of migrants within skill cells - i.e. a higher share of immigrants should lower the employment of natives who have similar skills.

\subsection{Estimation of the Immigration Impact}

Table 2 reports the estimated effects of immigration on native wages and employment for the main sample and various specifications. Since all the

45 Alternative mechanisms may also explain why immigrants are more willing to accept lower wages and non-standard hours than equally skilled natives. For instance, in Galor and Stark (1991), the possibility of returning to their (low-wage) country of origin creates strong incentives among immigrants to exert much more effort than natives. 
Table 2: The impact of the immigrant share on native outcomes (baseline sample).

\begin{tabular}{|c|c|c|c|c|}
\hline \multirow{2}{*}{ Specification } & \multicolumn{4}{|c|}{ Dependent variable } \\
\hline & $\begin{array}{r}\text { Monthly } \\
\text { wage }\end{array}$ & $\begin{array}{r}\text { Hourly } \\
\text { wage }\end{array}$ & $\begin{array}{r}\text { Employment } \\
\text { rate to } \\
\text { population }\end{array}$ & $\begin{array}{r}\text { Employment } \\
\text { rate to labor } \\
\text { force }\end{array}$ \\
\hline 1. Baseline regression & $\begin{array}{r}-0.41 \\
(-0.90)\end{array}$ & $\begin{array}{r}-0.35 \\
(-0.78)\end{array}$ & $\begin{array}{l}-0.36^{\star \star} \\
(-2.57)\end{array}$ & $\begin{array}{l}-0.32^{\star \star} \\
(-2.73)\end{array}$ \\
\hline 2. Unweighted regression & $\begin{array}{r}-0.52 \\
(-1.12)\end{array}$ & $\begin{array}{r}-0.50 \\
(-1.02)\end{array}$ & $\begin{array}{l}-0.46^{\star \star} \\
(-2.61)\end{array}$ & $\begin{array}{l}-0.34^{\star *} \\
(-2.55)\end{array}$ \\
\hline 3. Include log of natives as regressor & $\begin{array}{r}-0.42 \\
(-0.89)\end{array}$ & $\begin{array}{r}-0.34 \\
(-0.75)\end{array}$ & $\begin{array}{l}-0.34^{\star \star} \\
(-2.50)\end{array}$ & $\begin{array}{l}-0.31^{\text {** }} \\
(-2.65)\end{array}$ \\
\hline 4. Experience $\in] 5 ; 35]$ & $\begin{array}{r}-0.02 \\
(-0.05)\end{array}$ & $\begin{array}{r}0.07 \\
(0.14)\end{array}$ & $\begin{array}{c}-0.32^{\star} \\
(-1.76)\end{array}$ & $\begin{array}{c}-0.29^{\star} \\
(-1.89)\end{array}$ \\
\hline 5. $t=6$ & $\begin{array}{r}-0.55 \\
(-0.98)\end{array}$ & $\begin{array}{r}-0.41 \\
(-0.72)\end{array}$ & $\begin{array}{c}-0.36^{\star} \\
(-1.86)\end{array}$ & $\begin{array}{c}-0.34^{\star} \\
(-1.90)\end{array}$ \\
\hline 6. High education & $\begin{array}{r}-0.03 \\
(-0.05)\end{array}$ & $\begin{array}{r}-0.40 \\
(-0.62)\end{array}$ & $\begin{array}{r}-0.16 \\
(-1.10)\end{array}$ & $\begin{array}{r}-0.16 \\
(-1.58)\end{array}$ \\
\hline 7. Medium and low education & $\begin{array}{r}-0.66 \\
(-1.02)\end{array}$ & $\begin{array}{r}-0.67 \\
(-1.06)\end{array}$ & $\begin{array}{c}-0.35^{*} \\
(-2.08)\end{array}$ & $\begin{array}{c}-0.32^{\star} \\
(-2.00)\end{array}$ \\
\hline
\end{tabular}

$\star \star \star *, * \star$ * Statistical significance from zero at the $1 \%, 5 \%, 10 \%$ significance level. $t$-Statistics are indicated in parentheses below the point estimate.

Notes: The table reports the estimated effects of the immigrant share on native outcomes. The first group of outcomes captures male native wages (columns 1 and 2), whereas the second group measures their labor market opportunities (columns 3 and 4). These variables are computed for each education-experience group at time $t$ which composed the baseline sample ( 3 education groups $\times 8$ experience groups $\times 13$ years). Except for specification 6, all regressions include education, experience and period fixed effects, as well as interactions between education and experience fixed effects, education and period fixed effects and experience and period fixed effects. Specifications 1, 2 and 3 use 312 observations. Specifications 4 and 5 , respectively, use 234 and 144 observations. In specifications 6 and 7, I use 104 and 208 observations, respectively. Unless otherwise specified, each regression is weighted by the number of male natives used to compute the dependent variable. Standard errors are adjusted for clustering within education-experience cells.

regressions are based on annual variations, the estimates capture the short-run effects of immigration. Having data from 1990 to 2002, setting $j=3$ (education groups) and $k=8$ (experience groups), the estimates of Table 2 are based on a perfectly balanced sample of 312 observations.

In Section C of Supplementary Material, I provide the estimated effects of immigration for both alternative samples (Tables 11 and 12). Tables 11 and 12, respectively, provide estimates from a balanced sample of 156 (3 education groups $\times 4$ experience groups $\times 13$ years) and 312 (6 education groups $\times 4$ 
experience groups $\times 13$ years) observations. I use four dependent variables: the log monthly wage (column 1), the log hourly wage (column 2), the log employment rate to population (column 3) and the log employment rate to labor force (column 4). As in Borjas (2003), regressions are weighted by the number of male natives used to calculate the dependent variable.

The estimates reported in Tables 2, 11 and 12 show a robust adverse impact of the immigrant share on the employment of natives, but not on their wages. First, the insensitivity of wages to immigration is consistent with the prevalence of downward wage rigidities in France. ${ }^{46}$ Second, the estimates report evidence of a strong displacement effect. This corroborates the idea that immigrants are relatively more attractive for firms.

The first specification (row 1) reports the baseline estimates of $\beta$. For the three samples, the estimated wage effects of immigration are insignificant. Conversely, the estimated effects of immigration on the employment rates are significantly negative. The estimated coefficients in columns 3 and 4 are very close. This suggests that the share of immigrants has a very limited impact on the participation rate of natives. In other words, immigration does not discourage natives from seeking a job.

The estimates from the first specification (column 4) reported in Tables 2, 11 and 12 , respectively, imply that a $10 \%$ rise in the immigrant labor supply decreases the native employment rate to labor force by $2.7 \%(0.32 \times 0.84)$,

46 The estimated effects of immigration on wages are insignificant, although negative. The fact that I do not have an exhaustive dataset might affect the precision of my estimates, as explained in Aydemir and Borjas (2011), so that the true effect of immigration on wages might be actually negative. However, I reject this possibility for three reasons. First, the fact that immigration does not affect the French wage structure is consistent with the prevalence of strong downward wage rigidities in France (Section 2.1). In this regard, Card, Kramarz, and Lemieux (1999) found that negative economic shocks tend to have no detrimental effect on the wages of workers in France due to wage rigidities (as opposed to the United States). My results are also consistent with the study by Glitz (2012) who found for Germany no wage reactions due to immigration on competing natives. Second, even when I use alternative samples where the sample size per cell becomes substantially higher (see specification 6 and Table 11), the estimated coefficients remain insignificant. Third, the decomposition of native workers (in Section 5) according to whether they hold short-term or permanent contracts provides strong empirical evidence supporting the idea that French wages are insensitive to immigration because of wage rigidities. More specifically, when I focus on the native workers under permanent contracts (who are strongly affected by downward wage rigidities), the wage impact of immigration becomes even more insignificant. However, I find a strong and significant negative wage effect by focusing exclusively on the natives under short-term contracts, who are less subject to wage rigidities. 
$5.9 \%(0.70 \times 0.84)$ and $3.8 \%(0.44 \times 0.84) .{ }^{47}$ The alternative samples (in Supplementary Material) indicate higher negative effects on native employment. The effect of the immigrant share doubles from Table 2 (3 education groups $\times 8$ experience groups $\times 13$ years) to Table 11 (3 education groups $\times 4$ experience groups $\times 13$ years). The gap between the estimated coefficients is consistent with the prevalence of measurement bias in the computation of the immigrant share (Aydemir and Borjas 2011). Finally, the negative effect on native employment persists even when the sample with six education groups is used. This illustrates that the displacement mechanism is not driven by an educational downgrading among immigrants. This result is consistent with Docquier, Ozden, and Peri (2013) who find that highly educated immigrants are as likely to be in highly skilled occupation as natives.

The remaining rows of the tables conduct several robustness tests to determine the sensitivity of the baseline result to alternative specifications. In the second specification, I do not weight regressions. In the third row, I include the $\log$ of the number of natives in the workforce as an additional regressor. This specification controls for the fact that the evolution of the immigrant share may be driven by the native labor supply (Bratsberg et al. 2014).

The levels of wages and employment for the youngest and the oldest workers are strongly volatile from one year to another (Tables 7 and 8). Thus, I run regressions without the first and last experience groups (specification 4). In Table 2, the wage effect of immigration on wages becomes totally insignificant. However, specification 4 is not suitable for the samples in Supplementary Material since they are composed of four experience groups only. For both samples, specification 4 thus leads to a huge decline in observations. This should explain why the estimated employment effects become insignificant.

Finally, specification 5 removes the year 1990 and merges the following pairs of years: 1991/1992, 1993/1994, 1995/1996, 1997/1998, 1999/2000 and 2001/ 2002. This leads to a substantial increase in the sample size per skill cell, attenuating measurement errors (Aydemir and Borjas 2011). While the variance tends to be higher, the results in row 5 suggest that the previous estimates are unlikely affected by attenuation bias.

The last two rows decompose the immigration impact by education group. Specifications 6 and 7 investigate the immigration impact within the high schooling group and within both the medium and low schooling groups,

47 In order to convert $\hat{\beta}$ to an elasticity, it has to be multiplied by $1 /\left(1+m_{j k t}\right)^{2}$, with $m_{j k t}=M_{j k t} / N_{j k t}$. The mean value of the relative number of immigrants $m$ is about $9.1 \%$ over the period. See Borjas (2003); Aydemir and Borjas (2007) for further details and a formal derivation. 
respectively. ${ }^{48}$ However, the estimates from specifications 6 and 7 must be interpreted with caution. First, the number of observations to run regressions declined dramatically. Second, for the samples with three education groups (Tables 2 and 11), specification 6 cannot control for changes in the return to experience or education over time.

The results do not provide robust evidence of any detrimental effect on native wages. Moreover, the estimates show that highly educated immigrants do not depress the employment of comparably skilled natives. It seems that the sample of medium- and low-educated immigrants is the group that is driving much of the analysis. ${ }^{49}$ These results suggest that the displacement mechanism tends to operate only within the group of medium- and low-educated individuals. This is consistent with the idea that high-educated immigrants may have higher outside options and closer cultural norms than natives, as compared to the migrants with low level of education (Wilson and Jaynes 2000).

All in all, the share of immigrants, and therefore immigration, does not affect the wages of competing native workers, but induces adverse employment effects. Already discussed, the potential endogenous selection of migrants into skill cells would lead to upward biased estimates of $\beta$. Therefore, if this bias was addressed, the conclusions would be strengthened: the negative effect on native employment should be even stronger, implying a much more powerful displacement mechanism.

\section{The Wage Effects of Immigration by Job Contracts}

The previous results indicate that immigration does not affect the wages of competing workers. This result differs from Aydemir and Borjas (2007) who find a significant inverse relation between immigrant-induced shifts in labor supply and wages for Canada and the United States. The discrepancy in the wage reactions between France and North American countries is probably due to the prevalence of downward wage rigidities in France.

48 More precisely, Tables 2 and 11 (samples with three education groups) report the estimated impact of immigration within the highest education group (specification 6) and the two lowest (specification 7), while Table 12 (sample with six education groups) focuses on the two highest (specification 6) and the four lowest (specification 7).

49 The fact that the outcomes of low-skilled native workers tend to be the most affected by immigration is consistent with Jaeger (1996); Camarota (1997); Borjas (2003). They show that immigration has particularly reduced the wages of low-skilled natives in the United States. 
In order to show that the insensitivity of French wages to immigration is due to wage rigidities, this section uses the heterogeneity of native workers in terms of their employment contract. In fact, the type of employment contract is an important determinant of (downward) wage rigidity in France (Section 2.1). Thus, an immigrant-induced supply shift should have an asymmetric impact on the wages of competing native workers according to whether they have permanent or short-term contracts. While the insensitivity of French wages to immigration may be driven by the population of permanent workers, immigration should depress the wages of the natives under short-term contracts. ${ }^{50}$

Table 3 provides the estimated immigration impact on the outcomes of native workers under permanent contracts (left-hand side) and short-term contracts (right-hand side) for the baseline sample. Two dependent variables are used: the log monthly wage and the log hourly wage. The variable of interest $p_{j k t}$ is identical to the one used previously. The upper part of the table uses the main specifications from Table 2.

The left-hand side of Table 3 shows that an immigration-induced supply shift has no detrimental impact on the wages of competing native workers with permanent contracts (i.e. $91 \%$ of native workers). In Table 3, the estimated coefficients are smaller (in absolute value) and much more insignificant, compared to my previous estimates. Having a permanent contract therefore protects from any downward wage pressure. This set of results supports the idea that the French wage structure is insensitive to immigration because of wage rigidities.

Instead, the estimated effects of immigration on the wages of competing native workers with short-term contracts are negative and significant. This is consistent with Section 2.1 and economic theory. When wages are flexible, immigration lowers the wage of native workers with similar skills.

The baseline estimate implies that a $1 \%$ increase in the immigrant share reduces the monthly wages of native workers with a short-term contract by $2.5 \%$. Despite this magnitude is in line with Monras (2013), ${ }^{51}$ our point estimates might seem very large. Four considerations can be raised to understand why. First, the subsample of workers

50 One limitation of this exercise is that workers of similar education and experience may (systematically) differ according to whether they are covered by permanent or short-term contracts. Within a skill cell, both types of workers may compete for different types of jobs, and they might not be equally productive. I examine this precise issue by estimating the elasticity of substitution between workers under short-term and permanent contracts using a CES framework (Borjas 2003; Ottaviano and Peri 2012). Across a wide range of specifications, I find that they are perfect substitutes in production. Within a skill cell, the workers under both contracts are therefore similar in terms of their productivity.

51 For the United States, he shows evidence of a substantial decline of low-skilled wage due to Mexican immigrants at the state level. Whereas this work does not study the direct effect of 
Table 3: The immigration impact on the wages of natives with short and permanent contracts.

\begin{tabular}{|c|c|c|c|c|}
\hline \multirow[t]{2}{*}{ Specification } & \multicolumn{2}{|c|}{$\begin{array}{r}\text { Permanent contract } \\
\text { workers }\end{array}$} & \multicolumn{2}{|c|}{ Short-term contract workers } \\
\hline & Monthly wage & $\begin{array}{r}\text { Hourly } \\
\text { wage }\end{array}$ & Monthly wage & $\begin{array}{r}\text { Hourly } \\
\text { wage }\end{array}$ \\
\hline 1. Baseline regression & $\begin{array}{r}-0.17 \\
(-0.38)\end{array}$ & $\begin{array}{r}-0.12 \\
(-0.27)\end{array}$ & $\begin{array}{l}-3.21^{\star \star} \\
(-2.42)\end{array}$ & $\begin{array}{l}-2.98^{\star \star} \\
(-2.22)\end{array}$ \\
\hline 2. Unweighted regression & $\begin{array}{r}-0.35 \\
(-0.76)\end{array}$ & $\begin{array}{r}-0.34 \\
(-0.70)\end{array}$ & $\begin{array}{l}-3.54^{\star} \\
(-1.95)\end{array}$ & $\begin{array}{l}-3.38^{\star} \\
(-2.00)\end{array}$ \\
\hline 3. Include log of natives as regressor & $\begin{array}{r}-0.17 \\
(-0.37)\end{array}$ & $\begin{array}{r}-0.11 \\
(-0.23)\end{array}$ & $\begin{array}{l}-3.38^{\star \star} \\
(-2.77)\end{array}$ & $\begin{array}{l}-3.14^{\star} \\
(-2.46)\end{array}$ \\
\hline 4. Experience $\in] 5 ; 35]$ & $\begin{array}{r}0.25 \\
(0.50)\end{array}$ & $\begin{array}{r}0.29 \\
(0.59)\end{array}$ & $\begin{array}{l}-4.43^{*} \\
(-2.08)\end{array}$ & $\begin{array}{l}-4.48^{\star \star} \\
(-2.17)\end{array}$ \\
\hline 5. $t=6$ & $\begin{array}{r}-0.34 \\
(-0.56)\end{array}$ & $\begin{array}{r}-0.21 \\
(-0.33)\end{array}$ & $\begin{array}{l}-3.37^{\star} \\
(-1.99)\end{array}$ & $\begin{array}{l}-3.07^{\star} \\
(-1.77)\end{array}$ \\
\hline 6. Experience $>10$ & $\begin{array}{r}0.11 \\
(0.22)\end{array}$ & $\begin{array}{r}0.17 \\
(0.34)\end{array}$ & $\begin{array}{l}-5.70^{\star \star \star} \\
(-3.29)\end{array}$ & $\begin{array}{l}-5.52^{\star \star \star} \\
(-3.28)\end{array}$ \\
\hline $\begin{array}{l}\text { 7. Experience }>10 \text { and private } \\
\text { sector only }\end{array}$ & $\begin{array}{r}-0.08 \\
(-0.13)\end{array}$ & $\begin{array}{r}-0.06 \\
(-0.10)\end{array}$ & $\begin{array}{l}-6.42^{\star \star \star} \\
(-5.58)\end{array}$ & $\begin{array}{l}-6.28^{\star \star \star} \\
(-5.04)\end{array}$ \\
\hline
\end{tabular}

$\star \star \star, * \star$, *Statistical significance from zero at the $1 \%, 5 \%, 10 \%$ significance level. $t$-Statistics are indicated in parentheses below the point estimate.

Notes: The table reports the estimated impact of immigration on the wages of native workers who have permanent contracts (left-hand side) and short-term contracts (right-hand side). Specifications 1, 2 and 3 use 312 observations. Specifications 4 and 5, respectively, use 234 and 144 observations. In specifications 6 and 7, I use 234 observations. Unless otherwise specified, each regression is weighted by the number of male natives used to compute the dependent variable. Standard errors are adjusted for clustering within education-experience cells.

who hold short-term contracts is very specific: as suggested by Figure 2, the wages of workers under short-term contracts tend to be highly sensitive to economic shocks. This is consistent with the main goal of the introduction of short-term contracts, which was to provide firms with the additional flexibility they needed to cope with higher demand uncertainty, accelerated technical change and fiercer international competition (Bentolila et al. 1994; Goux, Maurin, and Pauchet 2001; Saint-Paul and Cahuc 2009). Second, the wage effect due to immigration may be more detrimental when it is concentrated among a small proportion of workers (here, the workers under short-term contracts), rather than diffused to all the labor force. Third, as I use yearly data (in contrary to Borjas (2003), for instance, who use five waves of data from 1960

immigration on the competing natives, it even though finds that a $1 \%$ labor supply shock to a local labor market decreases wages of low-skilled US natives by $1.5 \%$. 
to 2000), my estimates capture the direct short-run effect of immigration on native wages. I thus omit potential labor market adjustments that might happen in the medium and long run through changes in the industry structure or the reallocation of native workers across occupations, two channels that should strongly attenuate the short-run immigration impact (Lewis 2005; Glitz 2012). Fourth, the decomposition by job contract induces a huge decline in the number of observations used to compute the dependent variables for the workers under short-term contracts. Thus, this decomposition may introduce some noise in the measure of wages for workers under short-term contracts, inducing identification problems. ${ }^{52}$ Although the estimated wage effect on temporary workers is probably not well identified, this set of results suggest that the native workers who are under short-term contracts represent a specific population that experiences wage losses due to immigration.

Finally, specifications 5 and 6 remove from the sample the native workers who tend to be affected by two other sources of wage rigidities: the high level of the minimum wage and the prominence of the public sector. ${ }^{53}$ Specification 5 thus focuses on cells with more than 10 years of experience, excluding the groups most affected by the minimum wage. In addition, row 6 eliminates public workers from the sample. Interestingly, the insensitivity of wages to immigration is even more striking for the natives with permanent contracts. Moreover, the estimated immigration impact on the wages of native workers under short-term contracts is much more negative and significant.

All in all, the estimates show that when wages can be manipulated by firms, immigration causes wage losses. This reinforces the results presented in Section 4.2: the insensitivity of French wages to immigration is very likely to be due to downward wage rigidities. The estimates also support that the type of job contract is a main determinant of wage rigidity.

\section{Migrant Heterogeneity and Native Employment}

\subsection{Naturalized and Non-naturalized Immigrants}

The results in Section 4.2 report evidence of a detrimental average impact of immigration on native employment in the short run. Until now, this paper has

52 However, this problem is very unlikely to affect the estimated impact of immigration on the wages of natives with permanent contracts since this subsample of workers is much more important.

53 The public sector might be less competitive than the private sector. Over the period, the average share of native workers in the public sector was around $20 \%$. 
considered all migrants as a homogeneous population. But are they all the same?

Actually, immigrants are very likely to be heterogeneous based on their citizenship status (naturalized/non-naturalized). More specifically, the naturalized immigrants should differ from the others because of higher levels of outside options and integration. First, immigrants who obtain the French citizenship are henceforth treated in the same way as native-born citizens in terms of the law. Thus, contrary to the other migrants, the naturalized migrants are eligible to all the social benefits, they no longer have constraints to renew their work permits and they fill all the requirements to have access to public jobs.

Second, given the strong requirements to acquire the French citizenship (see footnote 44), the naturalized immigrants should exhibit higher level of integration. Hence, naturalized immigrants are likely to have reference standards in terms of wages and work conditions which are very close to those of natives (Constant et al. 2010), as well as they might no longer be forced into a sort of "social hyper-correctness" (Sayad 1999).

Finally, the economic literature on citizenship finds strong processes of selfselection within the immigrant workforce relative to citizenship acquisition (see, e.g. Bratsberg, Ragan, and Nasir 2002; DeVoretz and Pivnenko 2005; Bratsberg and Raaum 2011; Steinhardt 2012). Thus, the naturalized immigrants should also differ from the other migrants based on their unobservable characteristics; e.g. they should have better language skills and higher potentials for assimilation (DeSipio 1987; Portes and Curtis 1987). The unobservable characteristics of the naturalized immigrants are very likely to be positively correlated with their reservation wages and their level of integration.

While the naturalized immigrants should strongly differ from the other migrants, they should also have very similar performance to natives. With higher levels of outside options and integration, the naturalized immigrants should adjust their labor market behaviors to those of natives. ${ }^{54}$ Consequently, the naturalized immigrants should be less profitable for firms compared to the non-naturalized immigrants. Hence, if the aforementioned displacement effect is due to differences between natives and immigrants in terms of outside options, cultural norms and behaviors, the naturalized immigrants should have a very limited impact on native employment. Conversely, the negative immigration

54 This is consistent with Bratsberg, Ragan, and Nasir (2002) for the United States and Steinhardt (2012) for Germany who demonstrate an immediate positive naturalization effect on wages and an accelerated wage growth in the years after the naturalization event. Similarly, Coutrot and Waltisperger (2009) found evidence that the work conditions of naturalized immigrants tend to be closer to those of natives. 
impact on employment should be exclusively driven by non-naturalized immigrants. I investigate this implication, and I divide the share of migrants between the share of naturalized immigrants $p_{j k t}^{\text {ned }}$ and the share of non-naturalized immigrants $p_{j k t}^{\text {non-ned }} .55$

However, the estimated impact of $p_{j k t}^{\text {ned }}$ on native employment might prove to be spurious because of a selection problem based on observable characteristics. ${ }^{56}$ In fact, immigrants who happen to be naturalized could systematically differ from the others in terms of education, experience, occupation, region of residence, etc. Thus, it might be that if naturalized immigrants do not affect native employment, this is not because they adopt the norms of natives, but because of these systematic differences. In order to address this selection problem, the study requires to compare the impact on native employment of two immigrant groups who have similar observable characteristics except in their citizenship status (naturalized/non-naturalized). In effect, a different estimated impact of these two groups on native employment would indicate that the levels of outside options and integration matter in shaping the labor market immigration impact.

In order to find a group of naturalized immigrants which does not differ from the non-naturalized in terms of observable characteristics, I use the propensity score matching (PSM) method. ${ }^{57}$ It allows to decompose the naturalized

$55 p_{j k t}^{\text {ned }}=\left(M_{j k t}^{\text {ned }} /\left(M_{j k t}+N_{j k t}\right)\right)$ and $p_{j k t}^{\text {non-ned }}=\left(M_{j k t}^{\text {non-ned }} /\left(M_{j k t}+N_{j k t}\right)\right)$, with $M_{j k t}^{\text {ned }}$ and $M_{j k t}^{\text {non-ned }}$, respectively, the number of naturalized immigrants and non-naturalized immigrants in the cell $j, k$ at time $t$. Table 10 in the Supplementary Material reports the share of naturalized and nonnaturalized individuals in the immigrant labor force over time (1990-2002). It shows a sufficient variation of the number of naturalized non-naturalized immigrants to identify the impact of each share on native employment.

56 Immigrants' decision to acquire the citizenship is also related to their unobservable characteristics, such as their willingness to stay in the host country, their ability to learn the history of their host country, their language skills and potentials for assimilation. Because these unobservable characteristics are very likely to be positively correlated with their reservation wages and level of integration (DeSipio 1987; Portes and Curtis 1987), the naturalized immigrants should be close to natives in terms of their labor market performance. In particular, the naturalized immigrants should be less willing to accept lower wages and harder working conditions than the non-naturalized immigrants. As a result, the fact that naturalized immigrants differ systematically from the non-naturalized in terms of their unobservable characteristics supports the decomposition of immigrants by citizenship status.

57 The implementation of the PSM is detailed thoroughly in the Supplementary Material, Section E. First, I describe the PSM procedure and detail the variables used to compute the probability to be naturalized among immigrants. Then, I implement the matching procedure with tests for the matching quality. Finally, I explain why the limitations inherent to PSM techniques are unlikely to challenge my conclusions. 
population into two subsamples: (i) the naturalized individuals who have similar observable characteristics to the other migrants (SC) and (ii) the naturalized individuals who differ from the other migrants in terms of their observable characteristics (DC). Thus, the first group of naturalized immigrants (SC) should be similar to the non-naturalized immigrants in terms of education level, experience, occupation, etc. except for their citizenship status. Then, so as to estimate (and compare) the impact of these different immigrant groups on native employment, I compute the following immigrant shares: $p_{j k t}^{\text {non-ned }},\left(p_{j k t}^{\text {ned }}\right)_{\mathrm{SC}}$ and $\left(p_{j k t}^{\text {ned }}\right)_{\mathrm{DC}}{ }^{58}$

An identification problem due to measurement errors might still affect the estimates. As the immigrant population is divided into groups, the number of observations per cell tends to decrease. Yet, this may lead to an attenuation bias due to sampling error in the measure of the immigrant supply shift (Aydemir and Borjas 2011). In order to increase the number of naturalized immigrants per cell, and in fine limit the attenuation bias, two specifications are introduced. Since the number of naturalized immigrants increased significantly after 1992 (Table 10), specification 5 is added to focus on the 1993-2002 period. The second specification (row 6) removes the year 1990 and transforms the time span into four periods. ${ }^{59}$

Table 4 shows the estimated impact of immigration on the native employment rate to labor force by decomposing the effect of naturalized and nonnaturalized immigrants. It is divided into two parts: the left-hand side provides the raw estimates (with the raw immigrant shares: $p_{j k t}^{\text {non-ned }}$ and $p_{j k t}^{\text {ned }}$ ), while the right-hand side shows the estimates after the implementation of the matching procedure.

First, all the estimates find that native employment is totally insensitive to the share of naturalized immigrants. The second set of estimates (right-hand side) also indicates that immigrants who do not differ from the non-naturalized individuals in terms of observable characteristics do not hurt native employment. Second, the negative effect of $p_{j k t}^{\text {non-ned }}$ on native employment is slightly higher and more significant than in Section 4.2. Thus, the adverse impact of immigration is mostly driven by the non-naturalized immigrants. Moreover, this

58 Over the 1990-2002 period, the number of immigrants is around 38,000. There is 9,000 naturalized and 29,000 non-naturalized individuals. Here, the PSM implementation leads to splitting the naturalized immigrants into 4,200 and 4,800 individuals to compute $\left(p_{j k t}^{\text {ned }}\right)_{\text {SC }}$ and $\left(p_{j k t}^{\text {ned }}\right)$ DC

59 I merge the following years together: 1991/1992/1993, 1994/1995/1996, 1997/1998/1999, 2000/2001/2003. 
Table 4: The impact of naturalized and non-naturalized immigrants on native employment.

\begin{tabular}{|c|c|c|c|c|c|}
\hline \multirow[t]{2}{*}{ Specification } & \multicolumn{2}{|c|}{$\begin{array}{r}\text { Raw estimates } \\
\text { (1st set of regressions) }\end{array}$} & \multicolumn{3}{|c|}{$\begin{array}{r}\text { Estimates after matching } \\
\text { (2nd set of regressions) }\end{array}$} \\
\hline & $p_{j k t}^{\text {non-ned }}$ & $p_{j k t}^{\text {ned }}$ & $p_{j k t}^{\text {non-ned }}$ & $\left(p_{j k t}^{\text {ned }}\right)_{\mathrm{SC}}$ & $\left(p_{j k t}^{\text {ned }}\right)_{\mathrm{DC}}$ \\
\hline 1. Baseline regression & $\begin{array}{l}-0.35^{\star \star \star} \\
(-2.86)\end{array}$ & $\begin{array}{r}-0.02 \\
(-0.07)\end{array}$ & $\begin{array}{l}-0.35^{\star \star \star} \\
(-2.87)\end{array}$ & $\begin{array}{r}0.00 \\
(0.01)\end{array}$ & $\begin{array}{r}-0.04 \\
(-0.09)\end{array}$ \\
\hline 2. Unweighted regression & $\begin{array}{l}-0.40^{\star \star \star} \\
(-2.89)\end{array}$ & $\begin{array}{r}0.08 \\
(0.23)\end{array}$ & $\begin{array}{l}-0.40^{\star \star \star} \\
(-2.86)\end{array}$ & $\begin{array}{r}0.13 \\
(0.31)\end{array}$ & $\begin{array}{r}0.04 \\
(0.09)\end{array}$ \\
\hline $\begin{array}{l}\text { 3. Include log of natives as } \\
\text { regressor }\end{array}$ & $\begin{array}{l}-0.34^{\star \star \star} \\
(-2.86)\end{array}$ & $\begin{array}{r}0.04 \\
(0.13)\end{array}$ & $\begin{array}{l}-0.34^{\star \star \star} \\
(-2.92)\end{array}$ & $\begin{array}{r}0.00 \\
(0.00)\end{array}$ & $\begin{array}{r}0.08 \\
(0.17)\end{array}$ \\
\hline 4. Experience $\in] 5 ; 35]$ & $\begin{array}{l}-0.33^{\star \star} \\
(0.88)\end{array}$ & $\begin{array}{r}0.23 \\
(-2.11)\end{array}$ & $\begin{array}{l}-0.34^{\star \star} \\
(-2.17)\end{array}$ & $\begin{array}{r}0.08 \\
(0.19)\end{array}$ & $\begin{array}{r}0.32 \\
(0.67)\end{array}$ \\
\hline 5. $t=6$ & $\begin{array}{l}-0.37^{\star \star} \\
(-2.11)\end{array}$ & $\begin{array}{r}0.01 \\
(-0.01)\end{array}$ & $\begin{array}{l}-0.36^{\star \star} \\
(-2.11)\end{array}$ & $\begin{array}{r}0.14 \\
(0.18)\end{array}$ & $\begin{array}{r}-0.12 \\
(-0.21)\end{array}$ \\
\hline 6. $t>1992$ & $\begin{array}{l}-0.34^{\star *} \\
(-2.08)\end{array}$ & $\begin{array}{r}-0.16 \\
(-0.42)\end{array}$ & $\begin{array}{l}-0.35^{\star \star} \\
(-2.10)\end{array}$ & $\begin{array}{r}-0.26 \\
(-0.54)\end{array}$ & $\begin{array}{r}-0.08 \\
(-0.16)\end{array}$ \\
\hline 7. $t=4$ & $\begin{array}{l}-0.53^{\star \star} \\
(-2.25)\end{array}$ & $\begin{array}{r}-0.05 \\
(-0.06)\end{array}$ & $\begin{array}{l}-0.51^{\star \star} \\
(-2.16)\end{array}$ & $\begin{array}{r}0.34 \\
(0.28)\end{array}$ & $\begin{array}{r}-0.32 \\
(-0.39)\end{array}$ \\
\hline
\end{tabular}

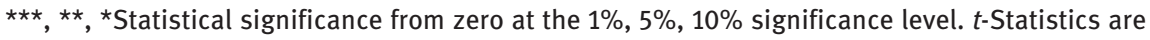
indicated in parentheses below the point estimate.

Notes: The table reports the estimated impact of immigration on native employment. I use the log employment rate to labor force as dependent variable. Each row provides the estimates from two regressions, one before (left-hand side) and one after (right-hand side) the matching procedure. Specifications 1, 2 and 3 use 312 observations. Specifications 4 and 5, respectively, use 234 and 144 observations. In specifications 6 and 7, I use 240 and 96 observations, respectively. Unless otherwise specified, each regression is weighted by the number of male natives used to compute the dependent variable. Standard errors are adjusted for clustering within education-experience cells.

result supports the fact that a labor supply shift induced by naturalized immigrants has no effect on native employment. ${ }^{60}$

In the short run, labor market competition mainly operates between workers with different level of outside options and different cultural norms - here, between natives and non-naturalized immigrants. Consequently, the native workers are only replaced by the non-naturalized immigrants.

60 More generally, all the previous estimates presented in Tables 2, 11 and 12 are robust to the decomposition of the immigrant population into naturalized and non-naturalized individuals. Thus, both groups of naturalized and non-naturalized immigrants have no effect on the French wage structure. 


\subsection{European and Non-European Immigrants}

By exploiting the heterogeneity of migrants by citizenship status, I find that nonnaturalized immigrants lower the employment of competing native workers. The previous estimates also indicate that a labor supply shift induced by naturalized immigrants has no detrimental impact on native employment. Actually, employers have an incentive to displace natives by the non-naturalized immigrants because the latter are relatively more attractive. They have lower outside opportunities and different cultural norms (as compared to both natives and naturalized immigrants).

This section is devoted to reinforce this result by going further into the decomposition of the immigrant population. In fact, the non-naturalized immigrants are composed of EU citizens and non-EU citizens; two immigrant groups that should also differ in terms of their outside options, cultural norms and labor market behaviors. ${ }^{61}$

First, the EU15 ${ }^{62}$ plus Norway, Iceland, Liechtenstein (as members of the European Economic Area) and Switzerland (through a bilateral treaty) "prohibit any kind of discrimination between native-born and migrants, regarding labor market accessibility and welfare benefits eligibility" (Razin 2013, 552 - see also Razin, Sadka, and Swagel 2002, 12) who explain that "immigrants in Europe have access to the full menu of welfare benefits regardless of whether or not they are citizens."63 European immigrants should therefore have higher employment opportunity and higher reservation wages than non-European immigrants. Second, a free migration regime as in Europe provides immigrants the

61 Another key segmentation in the immigrant labor force would have been between wellintegrated (old arrivals) and poorly integrated (recent arrivals) immigrants. In fact, well-integrated immigrants are very likely to be similar to natives in terms of cultural norms and labor market behaviors, so the former should be less willing to accept lower wages than the other migrants. As a result, immigrants with a longer time spent in France may be less detrimental for native employment than recent waves of immigrants. Unfortunately, this implication cannot be investigated since the immigrants' year of arrival is not provided by the data.

62 The EU15 countries regroup Austria (as of 1994), Belgium, Denmark, Finland (as of 1994), France, Germany, Greece, Italy, Luxembourg, Netherlands, Portugal, Spain, Sweden (as of 1994), United Kingdom.

63 See the Article 48 of the Rome Treaty (1957) which stipulates that "freedom of movement shall entail the abolition of any discrimination based on nationality between workers of the Member States as regards employment, remuneration and other conditions of work and employment." However, although EU citizens have far more privileges than non-EU citizens, notice that the French laws do not grant EU citizens exactly the same rights as natives in terms of labor market accessibility and welfare benefits eligibility. Small restrictions still remain - e.g. some public jobs need a French diploma to be performed. 
(additional) alternative to return to their home country anytime at lower cost. ${ }^{64}$ Finally, European immigrants come from countries that are economically and culturally closer to France than the non-European immigrants.

While the European immigrants should strongly differ from the nonEuropean migrants, they should also have very similar characteristics to both natives and naturalized immigrants. As a result, if the depressive immigration impact on native employment stems from the fact that immigrants have poor outside opportunities and different cultural norms; the reaction of native employment to immigration is expected to differ according to whether the increase in immigrant supply comes from European or non-European migrants. More specifically, the aforementioned negative employment effect due to nonnaturalized immigrants should be mainly driven by the non-European immigrants.

In order to investigate this implication, I decompose the non-naturalized immigrant population into two groups: the European, and the non-European immigrants. The group of Europeans includes all non-naturalized immigrants coming from the EU15 countries plus Norway, Iceland, Liechtenstein and Switzerland. The group of non-European immigrants includes the non-naturalized immigrants coming from outside these 19 countries. Then, I compute the share of European immigrants in the labor force $p_{j k t}^{\text {eur }}$, as well as the share of nonEuropean immigrants $p_{j k t}^{\text {oth }} \cdot{ }^{65}$ Over the period of analysis, $p_{j k t}^{\text {eur }}$ goes from $39.2 \%$ in 1990 to $24.0 \%$ in 2002; while $p_{j k t}^{\text {oth }}$ decreases from $54.4 \%$ in 1990 to $42.2 \%$ in 2002. Moreover, as shown in Edo and Toubal (2015), the educational distribution of European and non-European immigrants is very similar.

Table 5 reports the within-cell effect of $p_{j k t}^{\text {eur }}, p_{j k t}^{\text {oth }}$ and $p_{j k t}^{\text {ned }}$ (which is the share of naturalized immigrants) on native employment. The decomposition of the immigrant population into three subgroups leads to a decline in the number of observations available to compute $p_{j k t}^{\text {eur }}, p_{j k t}^{\text {oth }}$ and $p_{j k t}^{\text {ned }}$. As discussed above, a small sample size per cell $(j, k, t)$ to compute immigrant shares may bias the estimates due to measurement errors (Aydemir and Borjas 2011). In Table 5, I thus adopt two strategies to test the robustness of my results. First, in addition to using the baseline sample (with three education groups and eight experience groups), I also use the alternative structure of 12 skill cells only (three education groups and four experience groups). The last structure of education-experience

64 The freedom of movement and the ability to reside and work anywhere within the European Union are two of the fundamental rights which EU member states must recognize and this extends to Norway, Iceland, Liechtenstein and Switzerland.

65 As earlier I compute both shares as follows: $p_{j k t}^{\text {eur }}=\left(M_{j k t}^{\text {eur }} /\left(M_{j k t}+N_{j k t}\right)\right)$ and $p_{j k t}^{\text {oth }}=\left(M_{j k t}^{\text {oth }} /\left(M_{j k t}+N_{j k t}\right)\right)$. By construction, $p_{j k t}^{\text {eur }}+p_{j k t}^{\text {oth }}=p_{j k t}^{\text {non-ned }}$. 


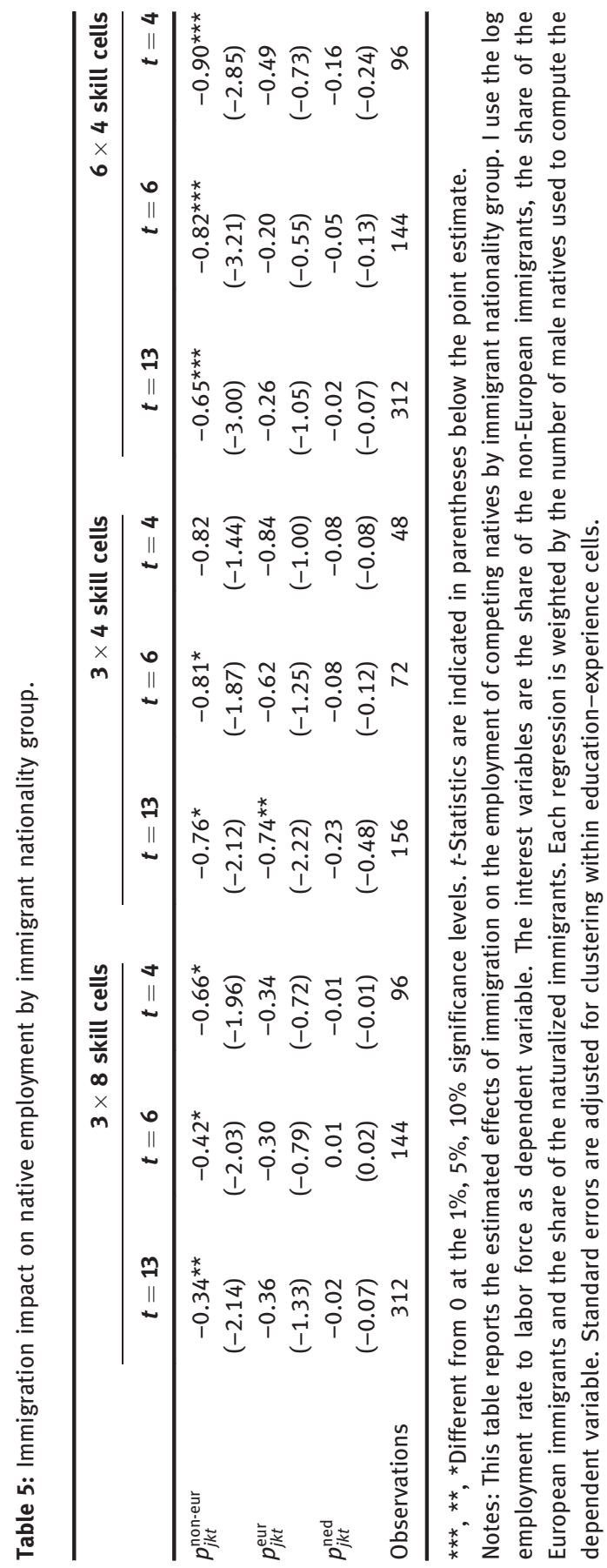


cells (with six education groups and four experience groups) is included to show that the results are not driven by any potential downgrading among immigrants.

Second, for each skill-cell structure, I use three specifications. While columns 1, 4 and 7 considered all years of the sample $(t=13)$, the other specifications remove the year 1990 from the sample and transforms the timespan into six $(t=6)$ and four $(t=4)$ periods (as in Section 6.1). This allows to substantially increase the sample size per skill cell $(j, k)$ as I merge years together.

In Table 5, the estimates indicate a significant negative relation between native employment and the share of non-European immigrants (except in column 6). This negative relation is stronger when I use four periods only $(t=4)-$ this is consistent with Aydemir and Borjas (2011) who show that an increase in the sample size per skill cell $(j, k)$ to compute the immigrant share allows to attenuate the bias of the immigration impact toward zero. When focusing on the sample with six education groups, the effect of non-European immigrants on native employment is always negative and significant at $1 \%$. This result shows that immigrants and natives compete within the same education group. Thus, the competition effect induced by an increase in the supply of non-European immigrants is more detrimental by defining fine education groups.

Although negative, the estimated coefficients on the share of European immigrants are mostly insignificant. This suggests that the employment of native workers tends to be insensitive to labor supply shifts induced by European immigrants. Finally, the estimated effects of naturalized immigrants on native employment are mostly negative but measured with very high imprecision, supporting that naturalized immigrants do not displace native workers. Taken together, the results presented in Table 5 indicate that the negative effect of immigration on native employment tends to be driven by the non-European immigrants - those immigrants with very low outside opportunities and different cultural norms.

\section{Conclusion}

This paper presents new evidence on the question of how immigration can decrease the wages and employment of competing native workers. The investigation focuses on the French labor market, which is characterized by rigid institutions.

In contrast with several studies which show a negative association between immigration and the wages of competing natives, I find no detrimental impact of immigration on wages. In order to show that the insensitivity of French wages to 
immigration is due to wage rigidities, I use the heterogeneity of native workers in terms of their employment contract. Contrary to permanent workers, I find that native workers under short-term contracts experience important wage losses due to immigration. This result is consistent with Babeckỳ et al. (2010) who show that permanent contracts have a strong effect on downward wage rigidity.

While immigration has no detrimental effect on average wages, the empirical analysis finds that immigration depresses the employment of competing native workers. I explain that immigrants displace the native workers because the former are more willing to accept lower wages and to exert more effort in production than natives - i.e. immigrants are relatively more attractive for firms. The heterogeneous effects of immigration on native employment by immigrant nationality group support this interpretation. I show that immigrants who acquired the French citizenship do not have any adverse impact on native employment. The detrimental employment effect of immigration is completely driven by the presence of non-naturalized immigrants (and especially, nonEuropean immigrants). With higher levels of outside options and integration, naturalized immigrants are as attractive as natives for firms. Therefore, naturalized immigrants do not replace the native workers in the production process.

When migrants and natives share similar outside options and cultural norms, and more generally similar behaviors, immigration no longer affects native employment. This last result may have policy implications. Economic policies that affect the outside options of immigrants should play a role in shaping the immigration impact on native outcomes. More specifically, economic policies implemented to protect the natives, by limiting the access for immigrants to the labor market and to social benefits, should decrease their outside options and may prove to be counter-productive - i.e. in disfavor of natives' labor market outcomes.

While they aim at protecting natives, these restrictions may actually exacerbate the competition between immigrants and natives, and, in fine, enhance the negative effect of immigration on the level of employment of competing workers. As a result, a way to attenuate the negative (partial) immigration impact on native outcomes would be to increase the outside options of immigrants, as well as to foster their cultural integration.

Acknowledgments: The author is grateful to the Centre Maurice Halbwachs (CMH) for having granted him access to the data set. The author's appreciation also goes to George Borjas, Gabriel Felbermayr, Lionel Fontagné, Julien Martin, Gianluca Orefice, Gianmarco Ottaviano, Farid Toubal and participants in various seminars, who provided him with insightful comments at several stages in the development of this work. Any errors that remain are of the author. 


\section{Supplemental data}

Supplemental data for this article can be accessed here.

\section{References}

Abowd, J. M., P. Corbel, and F. Kramarz. 1999. "The Entry and Exit of Workers and the Growth of Employment: An Analysis of French Establishments." Review of Economics and Statistics 81: $170-187$.

Abowd, J. M., and F. Kramarz. 2003. "The Costs of Hiring and Separations." Labour Economics 10: 499-530.

Algan, Y., C. Dustmann, A. Glitz, and A. Manning. 2010. "The Economic Situation of First and Second-Generation Immigrants in France, Germany and the United Kingdom." The Economic Journal 120: F4-F30.

Amossé, T., and M.-T. Pignoni. 2006. "La transformation du paysage syndical depuis 1945." Données sociales 405: 414.

Angrist, J. D., and A. D. Kugler. 2003. "Protective or Counter-Productive? Labour Market Institutions and the Effect of Immigration on EU Natives." The Economic Journal 113: F302-F331.

Avouyi-Dovi, S., D. Fougère, and E. Gautier. 2009. "Les négociations salariales en France: une analyse à partir de données d'entreprises (1994-2005).” Économie et Statistique 426: 29-65.

Aydemir, A., and G. J. Borjas. 2007. "Cross-Country Variation in the Impact of International Migration: Canada, Mexico, and the United States." Journal of the European Economic Association 5: 663-708.

Aydemir, A., and G. J. Borjas. 2011. "Attenuation Bias in Measuring the Wage Impact of Immigration." Journal of Labor Economics 29: 69-112.

Babeckỳ, J., P. Du Caju, T. Kosma, M. Lawless, J. Messina, and T. Rõõm. 2010. "Downward Nominal and Real Wage Rigidity: Survey Evidence From European Firms*." The Scandinavian Journal of Economics 112: 884-910.

Babeckỳ, J., P. Du Caju, T. Kosma, M. Lawless, J. Messina, and T. Rõõm. 2012. "How Do European Firms Adjust Their Labour Costs When Nominal Wages Are Rigid?” Labour Economics 19: 792-801.

Battisti, M., G. Felbermayr, G. Peri, and P. Poutvaara. 2014. "Immigration, Search, and Redistribution: A Quantitative Assessment of Native Welfare," Technical Report, National Bureau of Economic Research.

Bauer, T. K., M. Lofstrom, and K. F. Zimmermann. 2001. “Immigration policy, assimilation of immigrants, and natives' sentiments towards immigrants: Evidence from 12 OECD countries," Center for Comparative Immigration Studies.

Bentolila, S., J. J. Dolado, W. Franz, and C. Pissarides. 1994. "Labour Flexibility and Wages: Lessons from Spain." Economic Policy 9: 55-99.

Bevelander, P., and J. Veenman. 2006. "Naturalisation and socioeconomic integration: The Case of the Netherlands," Technical Report, IZA Discussion Papers. 
Blackaby, D. H., D. G. Leslie, P. D. Murphy, and N. C. O‘Leary. 2002. "White/Ethnic Minority Earnings and Employment Differentials in Britain: Evidence from the LFS." Oxford Economic Papers 54: 270-297.

Blanchard, O., and A. Landier. 2002. "The Perverse Effects of Partial Labour Market Reform: Fixed-Term Contracts in France." The Economic Journal 112: F214-F244.

Borjas, G. J. 2003. "The Labor Demand Curve Is Downward Sloping: Reexamining the Impact of Immigration on the Labor Market." The Quarterly Journal of Economics 118: 1335-1374.

Borjas, G. J. 2008. "Labor Outflows and Labor Inflows in Puerto Rico." Journal of Human Capital 2: 32-68.

Borjas, G. J. 2013. “The Analytics of the Wage Effect of Immigration.” IZA Journal of Migration 2: 22.

Borjas, G. J. 2014. Immigration Economics. Cambridge: Harvard University Press.

Borjas, G. J., J. Grogger, and G. H. Hanson. 2012. "Comment: On Estimating Elasticities of Substition." Journal of the European Economic Association 10: 198-210.

Borjas, G. J., and L. F. Katz. 2007. "The Evolution of the Mexican-Born Workforce in the United States." In Mexican Immigration to the United States (NBER Conference Report), 13-56. Cambridge: University of Chicago Press.

Bratsberg, B., and O. Raaum. 2011. "The Labour Market Outcomes of Naturalised Citizens in Norway." In OECD, Naturalization: A Passport for the Better Integration of Immigrants?, 184-210. OECD Publications.

Bratsberg, B., and O. Raaum. 2012. "Immigration and Wages: Evidence From Construction*." The Economic Journal 122: 1177-1205.

Bratsberg, B., O. Raaum, M. Røed, and P. Schøne. 2014. “Immigration Wage Effects by Origin.” The Scandinavian Journal of Economics 116: 356-393.

Bratsberg, B., J. F. J. Ragan, and Z. M. Nasir. 2002. "The Effect of Naturalization on Wage Growth: A Panel Study of Young Male Immigrants." Journal of Labor Economics 20: 568-597.

Brücker, H., and E. J. Jahn. 2011. "Migration and Wage-Setting: Reassessing the Labor Market Effects of Migration." The Scandinavian Journal of Economics 113: 286-317.

Cahuc, P., and F. Postel-Vinay. 2002. "Temporary Jobs, Employment Protection and Labor Market Performance." Labour Economics 9: 63-91.

Cahuc, P., and A. Zylberberg. 2004. Labor Economics. Cambridge, MA: MIT Press.

Caliendo, M., and S. Kopeinig. 2008. "Some Practical Guidance for the Implementation of Propensity Score Matching." Journal of Economic Surveys 22: 31-72.

Camarota, S. A. 1997. "The Effect of Immigrants on the Earnings of Low-Skilled Native Workers: Evidence from the June 1991 Current Population Survey." Social Science Quarterly 78: 417-31.

Card, D., F. Kramarz, and T. Lemieux. 1999. "Changes in the Relative Structure of Wages and Employment: A Comparison of the United States, Canada, and France." The Canadian Journal of Economics 32: 843-877.

Card, D., and T. Lemieux. 2001. "Can Falling Supply Explain the Rising Return to College for Younger Men? A Cohort-Based Analysis." The Quarterly Journal of Economics 116: 705-746.

Chassamboulli, A., and T. Palivos. 2014. "A Search-Equilibrium Approach to the Effects of Immigration on Labor Market Outcomes." International Economic Review 55: 111-129.

Chiswick, B. R., Y. L. Lee, and P. W. Miller. 2005. “Immigrant Earnings: A Longitudinal Analysis.” Review of Income and Wealth 51: 485-503. 
Cohen, D., A. Lefranc, and G. Saint-Paul. 1997. "French Unemployment: A Trans-Atlantic Perspective.” Economic Policy 12: 265-292.

Cohen-Goldner, S., and M. D. Paserman. 2011. "The Dynamic Impact of Immigration on Natives' Labor Market Outcomes: Evidence from Israel.” European Economic Review 55: 1027-1045.

Constant, A., A. Krause, U. Rinne, and K. F. Zimmermann. 2010. "Reservation wages of first and second generation migrants," DIW Berlin Discussion Paper No. 1089.

Corluy, V., I. Marx, and G. Verbist. 2011. "Employment Chances and Changes of Immigrants in Belgium: The Impact of Citizenship." International Journal of Comparative Sociology 52: 350-368.

Coutrot, D., and T. Waltisperger. 2009. "Les conditions de travail des salariés immigrés en 2005: plus de monotonie, moins de coopération," Première Synthèses Informations No. 09-2.

D‘Amuri, F., G. I. Ottaviano, and G. Peri. 2010. "The Labor Market Impact of Immigration in Western Germany in the 1990s.” European Economic Review 54: 550-570.

DARES. 2013. "Les Bénéficiaires de la Revalorisation du SMIC au 1er Janvier 2013," Technical Report, DARES Analyses No. 076.

d‘Autume, A., J.-P. Betbèze, J.-O. Hairault, et al. 2005. Les seniors et l'emploi en France. Paris: La Documentation française.

DeSipio, L. 1987. "Social Science Literature and the Naturalization Process." International Migration Review 21: 390-405.

DeVoretz, D., and S. Pivnenko. 2005. "The Economic Causes and Consequences of Canadian Citizenship." Journal of International Migration and Integration 6: 435-468.

Dickens, W. T., L. Goette, E. L. Groshen, S. Holden, J. Messina, M. E. Schweitzer, J. Turunen, and M. E. Ward. 2007. "How Wages Change: Micro-Evidence from the International Wage Flexibility Project." Journal of Economic Perspectives 21: 195-214.

Docquier, F., Ç. Ozden, and G. Peri. 2013. "The Labour Market Effects of Immigration and Emigration in OECD Countries." The Economic Journal 124(579): 1106-1145.

Du Caju, P., C. Fuss, and L. Wintr. 2009. "Understanding sectoral differences in downward real wage rigidity: workforce composition, institutions, technology and competition,” Technical Report, National Bank of Belgium.

Dustmann, C., T. Frattini, and I. P. Preston. 2013. "The Effect of Immigration along the Distribution of Wages." The Review of Economic Studies 80: 145-173.

Edo, A., and F. Toubal. 2015. "Selective Immigration Policies and Wages Inequality." Review of International Economics 23: 160-187.

Elsner, B. 2013a. "Does Emigration Benefit the Stayers? Evidence from EU Enlargement." Journal of Population Economics 26: 531-553.

Elsner, B. 2013b. “Emigration and Wages: The EU Enlargement Experiment." Journal of International Economics 91: 154-163.

Erdmans, M. P. 1995. “Immigrants and Ethnics.” The Sociological Quarterly 36: 175-195.

Euwals, R., J. Dagevos, M. Gijsberts, and H. Roodenburg. 2010. "Citizenship and Labor Market Position: Turkish Immigrants in Germany and the Netherlands1." International Migration Review 44: 513-538.

Felbermayr, G., W. Geis, and W. Kohler. 2010. "Restrictive Immigration Policy in Germany: Pains and Gains Foregone?" Review of World Economics 146: 1-21.

Foged, M., and G. Peri. 2013. "Immigrants and Native Workers: New Analysis Using Longitudinal Employer-Employee Data,” Technical Report, National Bureau of Economic Research. 
Fougere, D., and M. Safi. 2009. "Naturalization and Employment of Immigrants in France (1968-1999)." International Journal of Manpower 30: 83-96.

Friedberg, R. M. 2001. "The Impact of Mass Migration on the Israeli Labor Market.” The Quarterly Journal of Economics 116: 1373-1408.

Galor, O., and O. Stark. 1991. "The Probability of Return Migration, Migrants' Work Effort, and Migrants' Performance.” Journal of Development Economics 35: 399.

Gash, V., and F. McGinnity. 2007. "Fixed-Term Contracts - The New European Inequality? Comparing Men and Women in West Germany and France." Socio-Economic Review 5: 467-496.

Gerfin, M., and B. Kaiser. 2010. "The Effects of Immigration on Wages: An Application of the Structural Skill-Cell Approach." Swiss Journal of Economics and Statistics 146: 709-739.

Giuntella, 0. 2012. "Do Immigrants Squeeze Natives out of Bad Schedules? Evidence from Italy." IZA Journal of Migration 1: 1-21.

Glewwe, P. 1996. "The Relevance of Standard Estimates of Rates of Return to Schooling for Education Policy: A Critical Assessment.” Journal of Development Economics 51: 267-290.

Glitz, A. 2012. "The Labor Market Impact of Immigration: A Quasi-Experiment Exploiting Immigrant Location Rules in Germany." Journal of Labor Economics 30: 175-213.

Goux, D., E. Maurin, and M. Pauchet. 2001. "Fixed-Term Contracts and the Dynamics of Labour Demand.” European Economic Review 45: 533-552.

Hagedorn, H. 2001. "Republicanism and the Politics of Citizenship in Germany and France: Convergence or Divergence." German Policy Studies/Politikfeldanalyse 1: 243-272.

Hayfron, J. E. 2008. "The Economics of Norwegian Citizenship." In The Economics of Citizenship, edited by P. Bevelander and D. J. DeVoretz, 91-104. Malmö: Malmö University.

Heckman, J. J. 1979. "Sample Selection Bias as a Specification Error." Econometrica 47: 153-161. Heckman, J. J. 1993. "What Has Been Learned about Labor Supply in the Past Twenty Years?" The American Economic Review 83: 116-121.

Jaeger, D. A. 1996. "Skill Differences and the Effect of Immigrants on the Wages of Natives," US Bureau of Labor Statistics Working Paper 273.

Kahn, S. 1997. "Evidence of Nominal Wage Stickiness from Microdata." The American Economic Review 87: 993-1008.

Kee, P. 1995. “Native-Immigrant Wage Differentials in the Netherlands: Discrimination?" Oxford Economic Papers 47: 302-317.

Knoppik, C., and T. Beissinger. 2009. "Downward Nominal Wage Rigidity in Europe: An Analysis of European Micro Data from the ECHP 1994-2001." Empirical Economics 36: 321-338.

Kogan, I. 2003. "Ex-Yugoslavs in the Austrian and Swedish Labour Markets: The Significance of the Period of Migration and the Effect of Citizenship Acquisition." Journal of Ethnic and Migration Studies 29: 595-622.

Kramarz, F., and M. -L. Michaud. 2010. "The Shape of Hiring and Separation Costs in France." Labour Economics 17: 27-37.

Kuroda, S., and I. Yamamoto. 2003. "Are Japanese Nominal Wages Downwardly Rigid? (Part I): Examinations of Nominal Wage Change Distributions." Monetary and Economic Studies 21: 1-29.

Lebow, D. E., R. E. Saks, and B. A. Wilson. 2003. "Downward Nominal Wage Rigidity: Evidence from the Employment Cost Index." Advances in Macroeconomics 3: 1-28.

Lewis, E. G. 2005. "Immigration, skill mix, and the choice of technique," Federal Reserve Bank of Philadelphia Working Papers No. 05-8. 
Malchow-Møller, N., J. R. Munch, and J. R. Skaksen. 2012. "Do Immigrants Affect Firm-Specific Wages?” The Scandinavian Journal of Economics 114: 1267-1295.

Manacorda, M., A. Manning, and J. Wadsworth. 2012. "The Impact of Immigration on the Structure of Wages: Theory and Evidence from Britain." Journal of the European Economic Association 80(1): 145-173.

Math, A. 2011. "Minima sociaux: nouvelle préférence nationale?" Plein droit 3: 32-35.

Math, A., and A. Spire. 1999. "Des emplois réservés aux nationaux?" Informations sociales 78: $50-57$.

Mattoo, A., I. C. Neagu, and Ç. Özden. 2008. "Brain Waste? Educated Immigrants in the US Labor Market." Journal of Development Economics 87: 255-269.

Mayda, A. M. 2006. "Who Is Against Immigration? A Cross-Country Investigation of Individual Attitudes toward Immigrants." The Review of Economics and Statistics 88: 510-530.

Messina, J., C. F. Duarte, M. Izquierdo, P. Caju, and N. L. Hansen. 2010. "The Incidence of Nominal and Real Wage Rigidity: An Individual-Based Sectoral Approach.” Journal of the European Economic Association 8: 487-496.

Mincer, J. A. 1974. Schooling, Experience and Earnings. New York: Columbia University Press.

Monras, J. 2013. "Low skilled immigration and labor market outcomes: Evidence from the Mexican Tequila Crisis," Technical Report, Columbia University Discussion Paper Series.

Nickell, S. 1997. "Unemployment and Labor Market Rigidities: Europe versus North America." The Journal of Economic Perspectives 11(3): 55-74.

Orrenius, P. M., and M. Zavodny. 2007. "Does Immigration Affect Wages? A Look at OccupationLevel Evidence.” Labour Economics 14: 757-773.

Ortega, F., and G. Peri. 2009. "The Causes and Effects of International Migrations: Evidence from OECD Countries 1980-2005," Technical Report, National Bureau of Economic Research.

Ortega, J., and L. Rioux. 2002. "Durée des contrats et indemnisation du chômage." Revue Économique 53: 1273-1303.

Ottaviano, G. I., and G. Peri. 2008. "Immigration and national wages: Clarifying the theory and the empirics," Technical Report, National Bureau of Economic Research.

Ottaviano, G. I., and G. Peri. 2012. "Rethinking the Effects of Immigration on Wages." Journal of the European Economic Association 10: 152-197.

Portes, A., and J. W. Curtis. 1987. "Changing Flags: Naturalization and Its Determinants among Mexican Immigrants." International Migration Review 21(2): 352-371.

Rallu, J. L. 2011. "Naturalization Policies in France and the USA and Their Impact on Migrants' Characteristics and Strategies." Population Review 50(1): 40-61.

Razin, A. 2013. "Migration into the Welfare State: Tax and Migration Competition." International Tax and Public Finance 20: 548-563.

Razin, A., E. Sadka, and P. Swagel. 2002. "Tax Burden and Migration: A Political Economy Theory and Evidence." Journal of Public Economics 85: 167-190.

Rosenbaum, P. R., and D. B. Rubin. 1985. "Constructing a Control Group Using Multivariate Matched Sampling Methods That Incorporate the Propensity Score." American Statistician 39(1): 33-38.

Sá, F. 2011. "Does Employment Protection Help Immigrants? Evidence from European Labor Markets." Labour Economics 18: 624-642.

Saint-Paul, G., and P. Cahuc. 2009. Immigration, qualifications et marché du travail. Paris: La Documentation Francaise. 
Sartori, A. E. 2003. "An Estimator for Some Binary-Outcome Selection Models Without Exclusion Restrictions." Political Analysis 11: 111-138.

Sayad, A. 1999. "Immigration et "pensée d'État"." Actes de la recherche en sciences sociales 129: 5-14.

Scott, K. 2008. "The Economics of Citizenship: Is There a Naturalization Effect?" In The Economics of Citizenship, edited by P. Bevelander and D. J. DeVoretz, 107-126. Malmö: Malmö University.

Steinhardt, M. F. 2012. "Does Citizenship Matter? The Economic Impact of Naturalizations in Germany." Labour Economics 19(6): 813-23.

Thalhammer, E., V. Zucha, E. Enzenhofer, B. Salfinger, and G. Ogris. 2001. Attitudes towards Minority Groups in the European Union. Vie "DEG" "FP"nna: European Monitoring.

Thierry, X. 2004. "Évolution récente de l'immigration en france et éléments de comparaison avec le Royaume-Uni." Population 59: 725-764.

Weichselbaumer, D., and R. Winter-Ebmer. 2005. "A Meta-Analysis of the International Gender Wage Gap.” Journal of Economic Surveys 19: 479-511.

Wilson, F. D., and G. Jaynes. 2000. "Migration and the Employment and Wages of Native and Immigrant Workers." Work and Occupations 27: 135-167.

Yang, P. Q. 1994. “Explaining Immigrant Naturalization.” International Migration Review 28(3): 449-477. 